\title{
Spatio-temporal variability of warm rain events over southern West Africa from geostationary satellite observations for climate monitoring and model evaluation
}

Article

Accepted Version

Young, M. P., Chiu, J. C., Williams, C. J. R., Stein, T. H. M., Stengel, M., Fielding, M. D. and Black, E. (2018) Spatiotemporal variability of warm rain events over southern West Africa from geostationary satellite observations for climate monitoring and model evaluation. Quarterly Journal of the Royal Meteorological Society, 144 (716). pp. 2311-2330. ISSN 1477-870X doi: https://doi.org/10.1002/qj.3372 Available at https://centaur.reading.ac.uk/78951/

It is advisable to refer to the publisher's version if you intend to cite from the work. See Guidance on citing.

To link to this article DOI: http://dx.doi.org/10.1002/qj.3372

Publisher: Wiley

All outputs in CentAUR are protected by Intellectual Property Rights law, including copyright law. Copyright and IPR is retained by the creators or other copyright holders. Terms and conditions for use of this material are defined in the End User Agreement. 


\section{www.reading.ac.uk/centaur}

\section{CentAUR}

Central Archive at the University of Reading

Reading's research outputs online 


\title{
Spatiotemporal variability of warm rain events over southern West
}

\section{Africa from geostationary satellite observations for climate}

\section{monitoring and model evaluation}

\author{
Matthew P. Young ${ }^{\mathrm{a}, \mathrm{b}^{*}}$, J. Christine Chiu ${ }^{\mathrm{a}, \mathrm{c}, \mathrm{d}}$, Charles J. R. Williams ${ }^{\mathrm{b}}$, Thorwald H. M. \\ Stein $^{\mathrm{a}}$, Martin Stengel ${ }^{\mathrm{e}}$, Mark D. Fielding ${ }^{\mathrm{f}}$, Emily Black ${ }^{\mathrm{a}, \mathrm{b}}$ \\ ${ }^{\text {a }}$ Department of Meteorology, University of Reading, UK \\ ${ }^{b}$ National Centre for Atmospheric Science - Climate, UK \\ ${ }^{\mathrm{c}}$ Colorado State University, USA \\ ${ }^{\mathrm{d}}$ National Centre for Earth Observation, UK \\ ${ }^{\mathrm{e}}$ Deutscher Wetterdienst, Offenbach, Germany \\ ${ }^{\mathrm{f}}$ European Centre for Medium Range Weather Forecasts, UK \\ *Correspondence to Matthew P. Young, Lyle 508, Philip Lyle Building, University of \\ Reading, Reading, RG6 6BB, UK. E-mail: matthew.young@reading.ac.uk
}

\begin{abstract}
This paper presents the spatiotemporal variability of warm rain events over southern West Africa (SWA) during the summer monsoon season for the first time, using Spinning Enhanced Visible Infrared Radiometer (SEVIRI) observations on the Meteosat geostationary satellites. The delineation of warm rain events is based on the principle that precipitating low-level clouds are associated with either sufficient water content or large cloud droplet size.
\end{abstract}

This article has been accepted for publication and undergone full peer review but has not been through the copyediting, typesetting, pagination and proofreading process, which may lead to differences between this version and the Version of Record. Please cite this article as doi: $10.1002 / \mathrm{qj} .3372$ 
Capitalising on the ability of spaceborne radar to resolve vertical cloud structures and detect the presence of precipitation, the delineation is trained by collocated SEVIRI and CloudSat observations.

The resulting 12-years of observations from SEVIRI are used to examine the spatial, diurnal, seasonal and interannual variability of warm rain events over SWA. Warm rain events predominate during the monsoon in August, with little interannual variability, and persist over orography in the morning and the coasts after midday, likely enhanced by orographic lifting and land-sea breeze effects. Warm clouds have a much higher probability of precipitation along the coastlines of Liberia and Nigeria compared to the central SWA coastline and further inland. Finally, when evaluating an 8-day yet high-spatial resolution model simulation, we find that warm rain frequencies from the simulation agree well with SEVIRI near the coast but simulated warm cloud cover and thus warm rain frequencies are too low over the Gulf of Guinea. The probability of precipitation of warm clouds is also too low inland. The newly developed climatology creates opportunities to further investigate the diurnal cycle of warm rain, study aerosolcloud-precipitation interactions, and assess the role of warm rain in the water cycle across Africa and beyond.

Key Words: precipitation, warm rain, low-level clouds, West African monsoon, rainfall monitoring, remote sensing, SEVIRI

\section{Introduction}


Precipitation over southern West Africa (SWA) is important for agriculture and water resources, yet model simulations of precipitation amount and variability are uncertain over the region (e.g. Cook and Vizy, 2006; Roehrig et al., 2013; Vellinga et al., 2013; Dunning et al., 2017). Accurate observations of precipitation are therefore crucial for understanding the processes responsible for the model discrepancies. The majority of precipitation over SWA and the Sahel is produced by mesoscale convective systems (Mathon et al. 2002, Fink et al., 2006). These systems are fed by moisture transported inland from the Gulf of Guinea by low-level monsoon flow that frequently leads to the formation of warm clouds (Schrage et al., 2007; Knippertz et al., 2011; Schrage and Fink, 2012). Since these warm clouds are abundant over SWA during the monsoon in June-September (Stein et al., 2011; Bouniol et al., 2012; van der Linden et al., 2015), it is important to quantify how frequently they produce precipitation (i.e. warm rain) to help understand their lifetime, influence on the regional hydrological cycle and representation in models.

Robustly quantifying the probability of precipitation from warm clouds is also needed to understand the link between aerosols, cloud and precipitation over SWA. Aerosols from both natural (e.g. desert dust) and anthropogenic (e.g. pollution and biomass burning) sources are abundant and complex over the region (Knippertz et al., 2015), which may suppress warm rain (e.g. Rosenfeld et al., 2001; Lebsock et al., 2008; Mann et al., 2014) and in turn extend the warm cloud lifetime (Albrecht, 1989). The sensitivity of warm cloud probability of precipitation to aerosol perturbations has been used to constrain the response of liquid water path (LWP) to aerosols in climate models (Wang et al., 2012). 
Compared to rain gauge observations that have a poor spatial coverage, infrequent reporting rates and recent decline in numbers (Nicholson et al., 2001; Washington et al., 2006), satellite observations are the only viable dataset for monitoring rainfall over SWA. However, widely used satellite-based rainfall retrievals from passive Infrared (IR) and Microwave (MW) measurements primarily rely on signatures of cold cloud tops generated from deep convection, and thus fail to capture warm rain (Petty, 1999; Chen et al., 2011). This limitation has been speculated to be responsible for rainfall misrepresented by IR and MW-based retrievals over potentially warm-rain dominant regions of Africa including the Guinea Coast (Sealy et al., 2003; Nicholson et al., 2003), the Mozambique coast (Toté et al., 2016), the coast and highlands of Kenya (Tucker and Sear, 2001) and the Ethiopian Highlands (Young et al., 2014).

Warm rain events over SWA can be observed in two ways. First, spaceborne radar measurements provide detailed information on the vertical structure of clouds and precipitation, allowing us to distinguish between warm rain and other precipitation types. Observations from the Tropical Rainfall Measuring Mission (TRMM) Precipitation Radar (PR) reveal the presence of shallow precipitation over coastal regions of Africa (Schumacher and Houze, 2006; Fuentes et al., 2008; Liu and Zipser, 2009), although the PR is insensitive to light rain (less than $0.7 \mathrm{~mm} \mathrm{hr}^{-1}$; Kummerow et al., 1998), which may underestimate the frequency and amount of warm rain. The heterogeneity of precipitation within the relatively coarse PR footprint size of $\sim 4.3 \mathrm{~km}$ may also result in misclassifications of warm rain (Chen and $\mathrm{Fu}, 2016)$. In contrast, the 
vertically pointing cloud profiling radar (CPR) with a higher sensitivity and spatial resolution $(1.7 \mathrm{~km} \times 1.4 \mathrm{~km}$ footprint size; Tanelli et al., 2008) on the polar-orbiting CloudSat mission can detect light precipitation much better than the PR (Behranghi et al., 2014). Combining measurements from CloudSat and Cloud-Aerosol Lidar and Infrared Pathfinder Satellite Observations (CALIPSO) during 2006-2011, Mülmenstädt et al. (2015) showed that warm rain represents $10-20 \%$ of rainy profiles over SWA, with negligible warm rain fractions further inland.

Second, observations from passive sensors on-board geostationary satellites are appealing for monitoring warm rain characteristics at fine spatiotemporal scales, sufficient to resolve diurnal cycles and regional transitions of precipitation.

Previous studies have suggested that satellite retrievals of cloud effective radius exceeding $14-15 \mu \mathrm{m}$ typically indicate the onset of the warm rain process (Rosenfeld and Gutman 1994; Lensky and Rosenfeld, 1997; Painemal and Zuidema, 2011), in agreement with comparable thresholds of $10-15 \mu \mathrm{m}$ found from in-situ and aircraft measurements (vanZanten et al., 2005). Furthermore, retrievals of cloud effective radius and cloud optical depth from the Spinning Enhanced Visible and Infrared Imager (SEVIRI; Schmetz et al., 2002) on-board the Meteosat Second Generation satellites, have been shown to skilfully detect convective and stratiform precipitation events over mid-latitude Europe (Nauss and Kokhanovsky, 2006; Roebeling and Holleman, 2009). However, although these studies had the full spatiotemporal coverage of SEVIRI, they did not specifically examine warm rain events. In contrast, Chen et al. (2011) focussed solely on warm rain detection over the global oceans using two-months of 
collocated retrievals from CloudSat and the Moderate Resolution Imaging Spectroradiometer (MODIS), showing that a fixed threshold of MODIS LWP can skilfully detect warm rain. While this result is based on passive cloud property retrievals from a low-earth-orbiting sensor, it suggests that cloud property retrievals from a geostationary sensor could also potentially yield skilful warm rain detection while providing a much more complete spatiotemporal coverage at the same time.

The objective of this paper is 1) to characterise the frequency, geographic distribution and variability of daytime warm rain events over SWA during the monsoon season using SEVIRI observations; and 2) to illustrate how these new skilful fine-scale spatiotemporal observations of warm rain events can be used for evaluating and improving numerical weather prediction (NWP) models. Our warm rain delineation method is based on the same idea as Chen et al. (2011), but capitalises on SEVIRI cloud retrievals and uses a dynamic threshold of cloud effective radius to account for its interdependence on LWP and droplet number concentration. Although the SEVIRI cloud product is available only for daytime, and thus a full diurnal cycle of warm rain cannot be resolved, documenting the daytime statistics remains important because warm clouds are more frequent during daytime (Stein et al., 2011) and warm cloud coverage reaches its peak in the morning (van der Linden et al., 2015).

The rest of the paper is organised as follows. Satellite observations and other datasets used in this study are described in Sect. 2, while the development of the warm rain delineation method is detailed in Sect. 3. The resulting geostationary- 
based satellite observations of warm rain events over SWA and its application to model evaluation are presented in Sect. 4. Finally, the key findings and implications of these new observations of warm rain events are provided in Sect. 5.

\section{Data}

\subsection{Cloud property dataset using SEVIRI edition 2 (CLAAS-2)}

The new climatology of warm rain is derived from the CLoud property dAtAset using SEVIRI edition 2 (CLAAS-2, Benas et al., 2017), produced by the EUMETSAT Satellite Application Facility on Climate Monitoring (CM SAF). Specifically, we use CLAAS-2 cloud thermodynamic phase, cloud optical depth and effective radius on SEVIRI native temporal and spatial resolution (15 minutes and $3 \mathrm{~km}$ at nadir) for June-September, 2004-2015. The spatial coverage of the data includes Europe, Africa and the Atlantic Ocean.

Cloud optical depth and effective radius are retrieved by a lookup table approach assuming plane-parallel cloud layers, similar to the widely used cloud retrieval method described in Nakajima and King (1990) and Platnick et al. (2003). Lookup tables used in CLAAS-2 include reflectance at $0.6 \mu \mathrm{m}$ and 1.6 $\mu \mathrm{m}$ wavelengths for both liquid water and ice phases (Roebeling et al., 2006). For liquid water clouds, retrievals are provided with a range of optical depth from 0 to 256 and effective radii from 3 to $34 \mu \mathrm{m}$. The effective radius retrieval becomes uncertain for water clouds with optical depth less than 5; such water 
clouds are assigned a climatological effective radius of $8 \mu \mathrm{m}$ in the product (Benas et al., 2017). Additionally, effective radii smaller than $3.5 \mu \mathrm{m}$ are retrieved occasionally, due to very low reflectances observed in pixels classified to contain a liquid cloud. These retrievals are associated with relatively large uncertainty and therefore excluded. Such exclusions remove $\sim 3.4 \%$ of SEVIRI retrievals in the collocated warm cloud comparison performed in Section 4.

\section{2. $M O D I S$}

In addition to SEVIRI, we also use cloud products retrieved from MODIS on the Aqua satellite to assess whether thresholds required in the warm rain delineation method are sensitive to the cloud retrieval of choice, and whether the delineation performance is consistent across various operational satellite products. More importantly, we take advantage of the fact that Aqua is part of the A-train satellite constellation, providing near-coincident observations with CloudSat to generate an excellent match-up training dataset for the development of our delineation method (as explained in Sect. 3). As a result, the performance of warm rain delineation using MODIS is used as a benchmark to evaluate delineation results from SEVIRI.

The MODIS product (Collection 6; MOD06) provides retrievals of cloud thermodynamic phase, cloud optical depth and effective radius at $1 \mathrm{~km}$ resolution, available twice per day at 1330 and 0130 local time (Platnick et al., 2017). The shortwave-derived cloud phase retrieval in Collection 6 is determined by a confidence score built through a series of tests that examine 
cloud top temperature, IR-based cloud phase, the $1.38 \mu \mathrm{m}$ water vapour channel and retrieved cloud effective radius (Marchant et al., 2016). The retrieved cloud top temperature for optically thick warm clouds is given a high confidence score, since such clouds largely contribute to the observed shortwave radiance at the top of the atmosphere (TOA). But the use of cloud top temperature alone is problematic for optically thin clouds and multilayer clouds, where the TOA radiance may be interpreted as being radiated from the wrong altitude.

Therefore, the $1.38 \mu \mathrm{m}$ water vapour channel is used to help identify optically thin cirrus. Finally, the cloud phase retrieval is checked to see whether it is physically consistent with the cloud effective radius retrieval.

Like SEVIRI cloud retrievals, MODIS cloud optical depth and cloud effective radius are retrieved simultaneously via lookup tables using shortwave reflectance measurements at one water-absorbing wavelength and one non waterabsorbing wavelength. The choice of water absorbing wavelength can be 1.6 $\mu \mathrm{m}, 2.1 \mu \mathrm{m}$, or $3.7 \mu \mathrm{m}$, and the corresponding cloud effective radius retrievals are all available from the MODIS cloud product. Compared to retrievals at the $3.7 \mu \mathrm{m}$ wavelength, cloud effective radii retrieved from reflectance at the $1.6 \mu \mathrm{m}$ and $2.1 \mu \mathrm{m}$ wavelengths tend to be more sensitive to the presence of precipitation, due to the deeper photon penetration path at those two wavelengths (Rosenfeld et al., 2004; Nakajima et al., 2010; Suzuki et al., 2010). Our analysis primarily uses $2.1 \mu \mathrm{m}$ wavelength MODIS effective radius retrievals, because these lead to the best performance in warm rain delineation among the three wavelengths. 


\subsection{CloudSat and CALIPSO}

The CloudSat and CALIPSO satellites orbit at $705 \mathrm{~km}$ altitude, as part of the Atrain constellation crossing the equator twice per day. CloudSat carries a vertically pointing 94-GHz Cloud Profiling Radar (CPR) with a minimum detectable reflectivity of $-30 \mathrm{dBZ}$ (Stephens et al., 2002). CPR measurements are vertically resolved from the surface to $30 \mathrm{~km}$ altitude at a resolution of 240 $\mathrm{m}$; the footprint sizes along-track and across-track are $1.7 \mathrm{~km}$ and $1.4 \mathrm{~km}$, respectively. CALIPSO carries the dual (532 and $1064 \mathrm{~nm})$ wavelength CloudAerosol Lidar with Orthogonal Polarization (CALIOP) measuring lidar attenuated backscatter from both clouds and aerosols at an approximate horizontal and vertical resolution of $335 \mathrm{~m}$ and $30 \mathrm{~m}$, respectively (Winker et al., 2009).

Warm clouds are selected using the DARDAR-MASK product (version 1.1.4) which combines CPR and CALIOP observations with coincident atmospheric fields from the European Centre for Medium-Range Weather Forecasts (ECMWF) global analysis (Delanoë and Hogan, 2010; Ceccaldi et al. 2013). This synergistic approach for cloud detection is particularly useful as the CPR can penetrate through optically thick cloud layers that strongly attenuate the lidar signal, whereas the lidar can detect optically thin ice clouds and low-level liquid water clouds with small droplets that are otherwise missed by the CPR because of its limited sensitivity. In the DARDAR product, the CPR radar reflectivity and CALIOP attenuated backscatter at $532 \mathrm{~nm}$ are interpolated vertically to a common grid of $60 \mathrm{~m}$ and horizontally to the CPR footprint. 
Cloud layers are identified in the DARDAR product if the cloud mask from the CloudSat 2B-GEOPROF data product is greater than 30 (confident cloud detection; Marchand et al., 2008; Delanoë and Hogan, 2010), or if the CALIPSO Vertical Feature Mask identifies hydrometeors (Anselmo et al., 2006).

Precipitation incidence of warm clouds is derived using the CloudSat 2CPRECIP-COLUMN product. The product classifies CloudSat profiles into "no rain', 'rain possible' and 'rain certain' by applying a reflectivity threshold to near-surface CPR reflectivity (Haynes et al., 2009; Smalley et al., 2014). Over land, a profile is classified as 'rain certain' when the clutter-free reflectivity at $\sim 1200 \mathrm{~m}$ above the surface is greater than $5 \mathrm{dBZ}$, or when heavy attenuation is found in the profile (Smalley et al., 2014). When the observed reflectivity meets a lower threshold of $-5 \mathrm{dBZ}$ instead, it is classified as 'rain possible'. Over ocean surfaces where the ground-clutter effect is reduced, the reflectivity threshold can be applied to a lower altitude of $\sim 750 \mathrm{~m}$ with $0 \mathrm{dBZ}$ for 'rain certain' and $-15 \mathrm{dBZ}$ for 'rain possible' (Haynes et al., 2009). Note that drizzle and light rain could evaporate before reaching ground level; therefore, the higher thresholds used in the 'rain certain' category increase the likelihood that rain is heavy enough to reach the ground, providing precipitation incidence more consistent with surface observations (Ellis et al., 2009). In this study, we evaluate our warm rain detection method against both 'rain certain' and 'rain possible' categories to understand the impact of these reflectivity thresholds on the delineation results.

\section{Warm rain delineation methodology}


Based on ground-based active and passive remote sensing observations, Chiu et al. (2014) developed a drizzle delineation method for liquid water clouds, using the critical cloud effective radius $\left(r^{*}\right)$ as a threshold, defined as

$$
r^{*}=\frac{E}{\tau}
$$

which is a function of the cloud optical depth $(\tau)$ at visible wavelengths, and an empirically optimised coefficient $E(\mu \mathrm{m})$. Clouds are identified as precipitating if their corresponding cloud effective radius $r_{e}$ is larger than $r^{*}$; otherwise, clouds are non-precipitating. Since the product of $\tau$ and $r_{e}$ is proportional to LWP, the physical reasoning behind Eq. (1) is that clouds must contain a sufficient amount of liquid water as well as sufficiently large droplets (i.e. $\left.r_{e}>r^{*}\right)$ in order to precipitate. The criteria in LWP and $r_{e}$ need to be met simultaneously, because some clouds with large LWP do not precipitate due to their large number concentration and small droplet size; therefore, the use of a single threshold of LWP will possibly misclassify this type of clouds as precipitating. On the other hand, if the single threshold of LWP is set too high, precipitating clouds with relatively low LWP due to rain falling out of the system may be missed, even though the large droplet sizes associated with these clouds provide a clear indication of precipitation. The proposed method in Eq. (1) is therefore designed to improve detections for these problematic cases.

The coefficient $E(\mu \mathrm{m})$ depends on the geographical region, cloud type, and radar threshold used to define the presence of precipitation. For a threshold of - 
$15 \mathrm{dBZ}$ and for continental warm stratiform clouds, Chiu et al. (2014) found that a value of $380 \mu \mathrm{m}$ for $E$ led to the best Heidke Skill Score (HSS) for delineating drizzle. To adapt this method specifically for Africa, we use CloudSat observations to find the optimal $E$ for clouds observed by SEVIRI and MODIS, as explained next.

We collocate SEVIRI cloud retrievals with daytime overpasses of MODIS, CloudSat and CALIPSO observed in June-September, 2007-2010 over the panAfrican region of $40^{\circ} \mathrm{S}$ to $35^{\circ} \mathrm{N}, 20^{\circ} \mathrm{W}$ to $55^{\circ} \mathrm{E}$. Due to the 15 -min temporal resolution of SEVIRI retrievals, the maximum time difference between SEVIRI retrievals and others is $7.5 \mathrm{~min}$. Ideally the time difference should be as small as possible, so that cloud properties do not change dramatically between SEVIRI retrievals and others. However, using a shorter time window only lead to a much smaller sample size (e.g. the number of samples reduced by $84 \%$ when a time difference of $1 \mathrm{~min}$ was used instead of $7.5 \mathrm{~min}$ ), rather than improve confidence in the results. The collocated MODIS retrievals of optical depth and effective radius are averaged to match the nominal SEVIRI footprint size of $3 \mathrm{~km}$. A SEVIRI footprint is counted in warm cloud occurrence calculations when the following criteria are met: 1) the SEVIRI cloud phase retrieval is liquid water; 2) all MODIS cloud phase retrievals within the SEVIRI footprint are liquid water; and 3) the DARDAR cloud mask indicates a single liquid water cloud layer, without any overlying higher-level clouds. Within a SEVIRI footprint, if any CloudSat profile is 'rain certain' (see Sect. 2.3), then the footprint is classified as precipitating; otherwise, it is classified as non-precipitating. We also repeat the above analysis using 'rain possible' profiles from CloudSat, to understand how 
the optimal value of coefficient $E$ varies with the radar reflectivity threshold used for precipitation classification.

Each SEVIRI footprint has a pair of warm cloud observations from CloudSat and SEVIRI, as well as a pair from CloudSat and MODIS. Each pair forms its own contingency table (as shown in Table 1) that represents occurrences of hits (A), false alarms (B), misses (C) and correct negatives (D), respectively. Taking the pair of observations from CloudSat and SEVIRI as an example, a hit is counted when warm rain is detected by CloudSat and also by SEVIRI when the retrieved cloud effective radius exceeds the critical radius in Eq. (1) depending on the retrieved optical depth and coefficient $E$. A false alarm is counted when a warm rain event is not indicated by a CloudSat profile, but SEVIRI cloud properties suggest the presence of warm rain. To quantify the classification skill evaluated against CloudSat, we use the HSS that takes into account the expected skill obtained by chance in the absence of any skill (Barnston, 1992), defined as:

$$
H S S=\frac{2(A \cdot D-B \cdot C)}{(A+C)(C+D)+(A+B)(B+D)} .
$$

An HSS of 0 indicates no skill, while 1 represents perfect skill. We further determine the optimal value of $E$ by finding the location where the HSS is maximised. As a measure of uncertainty in the optimal $E$ and HSS, we also quantify the $90 \%$ confidence intervals of these two parameters by recalculating them 1000 times by bootstrap resampling the cloud properties. The $90 \%$ confidence interval gives a lower and upper limit of optimal $E$, which is then 
applied to cloud retrieval to provide an uncertainty estimate of warm rain frequency.

\section{Evaluation results}

\subsection{Intercomparison of HSS}

Before providing detailed evaluations on the delineation method, we first compare and examine the characteristics of single-layer warm clouds in the collocated SEVIRI and MODIS retrievals. Figure 1 shows that cloud optical depths and effective radii retrieved from SEVIRI and MODIS agree well over land and ocean, although effective radii over ocean from SEVIRI tend to be systematically smaller than those from MODIS. These findings are similar to those of Benas et al. (2017) where SEVIRI retrievals were compared with one MODIS overpass over Europe.

The joint histograms of cloud optical depth and effective radius in Figure 2 show that warm clouds over land tend to be optically thicker than those over ocean. Cloud droplet effective radii range mainly between 5-15 $\mu \mathrm{m}$, although

larger radii are not uncommon for both over land and over ocean. By separating the data into non-raining and raining retrievals, Figure 3 shows that raining clouds generally have larger optical depth and effective radius. The median effective radius of $\sim 20 \mu \mathrm{m}$ from SEVIRI and MODIS observations during warm rain events over ocean is consistent with Nakajima et al. (2010) and Suzuki et al. (2010) that found that MODIS cloud effective radii are typically greater than 20 
$\mu \mathrm{m}$ in the presence of rain. The coherent upward shift in the interquartile range of effective radius from non-raining to raining clouds indicates the strong link between cloud droplet size and the onset of warm rain.

Values of optimal coefficient $E$ and the corresponding HSS for detecting warm rain over land and ocean from SEVIRI and MODIS retrievals are summarised in Figure 4. Notably, the values found for these cloud products have a number of similar features. Firstly, the optimal $E$ is generally higher over land than over ocean (Fig. 4a). Note that

$$
N_{d} \propto \tau^{1 / 2} \cdot r_{e}^{-5 / 2}
$$

where $N_{d}$ is cloud droplet number concentration (Painemal and Zuidema, 2011; Painemal et al., 2017). Since the mean cloud effective radius of SEVIRI is surprisingly similar over land and ocean, but the cloud optical depth is larger over land (as shown in Figures 2 and 3), Eq. (3) then suggests a larger $N_{d}$ over land compared to ocean. Increased $N_{d}$ tends to suppress warm rain (Wood, 2005; Wood et al., 2011; Mann et al., 2014; and many others). Therefore, a larger optimal $E$ value (i.e., larger LWP) is required for warm clouds to precipitate over land.

Secondly, the optimal HSS is generally higher over ocean than over land (Fig. 4b). This skill degradation over land for both products may be caused by the uncertainty in cloud retrievals due to the heterogeneous land surface (e.g. King et al., 2003; Platnick et al., 2003; Christensen et al., 2013), and by the 
uncertainty in estimating un-attenuated radar reflectivity from a less-defined surface-backscatter over land (Haynes et al., 2009).

Thirdly, as expected, when a lower radar threshold is used for defining rain events (i.e., 'rain possible' rather than 'rain certain'), a smaller optimal $E$ is yielded (Fig. 4a). This is because the samples selected by the 'rain possible' threshold include more drizzle events and are not limited to heavier rain events selected by the 'rain certain' threshold (Fig. 4c); less total water content is therefore required for a cloud to be classified as precipitating. Furthermore, the sensitivity of HSS to the radar threshold behaves differently between over land and over ocean (Fig. 4b). Over ocean, a higher HSS is yielded from the 'rain possible' threshold, compared to 'rain certain'. This increase in skill when detecting 'rain possible' events resulted from many more hits and fewer false alarms, indicating that cloud retrievals from passive satellite observations have a great ability for capturing drizzle signals from warm clouds. In contrast, the optimal HSS over land is insensitive to the radar threshold, because the 'rain certain' threshold has already captured the majority of rain events, as shown in Figure 4c. Finally, the much larger sample size over ocean in Figure 4c leads to smaller uncertainties in optimal $E$ values and HSS, compared to those over land.

Compared to the optimal HSS derived from MODIS cloud retrievals, the delineation performance using SEVIRI is better over land, but relatively similar over ocean (as shown in Figure 4b). Investigation of contingency tables reveals that the higher skill of SEVIRI over land is because it misses fewer warm rain events and has fewer false detections than MODIS. Over land, the optimal $E$ 
ranges between 420 and $480 \mu \mathrm{m}$ for SEVIRI at the 'rain possible' threshold (Fig. 4a and Table 2). This is higher than the optimal $E$ of $380 \mu \mathrm{m}$ found by groundbased measurements of continental stratiform clouds in Oklahoma, USA (Chiu et al., 2014). Since our 'rain possible' threshold ( $-5 \mathrm{dBZ}$ over land $)$ is higher than the radar threshold used in their study $(-15 \mathrm{dBZ})$, the higher optimal $E$ value is expected for a cloud system producing higher precipitation rates. However, the optimal HSS of 0.4 from SEVIRI is lower than the HSS of 0.5 found by Chiu et al. (2014). Our lower optimal HSS may be partly caused by the larger uncertainty in SEVIRI retrievals due to cloud inhomogeneity within the relatively large footprint, and the difficulty of collocating SEVIRI retrievals with CloudSat in both time and space, which is much easier for ground-based measurements that have relatively high spatiotemporal resolutions.

Finally, we compare the detection skill from SEVIRI and MODIS over ocean with those reported in Chen et al. (2011), which analysed two-months (January and July, 2008) of MODIS/CloudSat data over ocean using a rain rate threshold of $1.2 \mathrm{~mm} \mathrm{day}^{-1}$. Since a rain rate in the order of $1 \mathrm{~mm}^{\text {day }}{ }^{-1}$ approximately corresponds to a radar reflectivity of $-5 \mathrm{dBZ}$ for marine boundary layer clouds (Fielding et al., 2015), the rain rate threshold used in Chen et al. (2011) is equivalent to our 'rain certain' scenario. Their highest HSS was obtained using a LWP threshold of $\sim 180 \mathrm{~g} \mathrm{~m}^{-2}$ (see their Table 1). Assuming that cloud liquid water content is constant in the vertical (Stephens, 1978), LWP can be calculated by

$$
L W P=\frac{2}{3} \rho_{w} \cdot \tau \cdot r_{e}
$$


where $\rho_{w}$ is the water density. Comparing Equation (4) to (1), the LWP threshold of $\sim 180 \mathrm{~g} \mathrm{~m}^{-2}$ is then equivalent to a coefficient $E$ of $270 \mu \mathrm{m}$. If assuming that $N_{d}$ is constant and liquid water content increases linearly with height (Wood and Hartmann, 2006), LWP can be calculated by

$$
L W P=\frac{5}{9} \rho_{w} \cdot \tau \cdot r_{e}
$$

Then, the LWP threshold of $\sim 180 \mathrm{~g} \mathrm{~m}^{-2}$ is equivalent to a coefficient $E$ of $\sim 320$ $\mu \mathrm{m}$. Either way, the equivalent value of coefficient $E$ is smaller than our optimal $E$ of $380 \mu \mathrm{m}$ for MODIS over ocean using the 'rain certain' threshold (Table 2). Although there are some differences in the definition of precipitating events and the threshold used, our optimal HSS of 0.47 is close to 0.5 found by Chen et al. (2011). The robustness in the HSS magnitude suggests that $\sim 0.5$ may be the best skill score we can achieve for delineating warm rain over ocean from collocated MODIS and CloudSat observations.

\subsection{Intercomparison during an independent case on 24 July 2006}

We now further examine the performance of the warm rain delineation method in detail, using a CloudSat overpass at the coast and inland over SWA on 24 July 2006 as an example. This case is not part of the training dataset (JuneSeptember, 2007-2010) used to optimise the delineation method, and thus provides an independent evaluation. In this overpass, CloudSat radar reflectivity (Figure 5a) shows a number of intermittent precipitating cells with cloud tops 
below the freezing level of $\sim 5 \mathrm{~km}$. In general, warm rain delineation from SEVIRI agrees relatively well with CloudSat for the precipitation cells, but misses some parts of the precipitating transect at $4.5^{\circ} \mathrm{N}-5^{\circ} \mathrm{N}$ and misclassifies some clouds as precipitating. MODIS cloud retrievals detect fewer false alarms, but also fewer warm rain occurrences, e.g., some misses particularly between $6^{\circ} \mathrm{N}-6.7^{\circ} \mathrm{N}$. Note that at $\sim 6.7^{\circ} \mathrm{N}$ MODIS optical depth and effective radius retrievals failed and therefore MODIS appears to 'miss' the warm rain events there. Such retrieval failures from MODIS can be expected especially over inhomogeneous cloud scenes where the observed reflectance does not fall within the range of reflectances in the retrieval look-up-table (Cho et al., 2015). However, any failed retrievals are excluded from the analysis presented in Section 4.1 and therefore do not affect the results there.

Carefully comparing the warm rain locations in Figure 5a with Figures $5 \mathrm{~b}$ and $5 \mathrm{c}$, we can see that these locations are strongly influenced by the retrieved cloud optical depth. Since MODIS retrievals have a finer horizontal resolution than SEVIRI, the peaks of the MODIS cloud optical depth align very well with the precipitation cells shown in Figure 5a, and thus MODIS delineation has fewer false alarms. The warm rain locations determined by SEVIRI retrievals also strongly correlate to the peaks of cloud optical depth but are also effected by large effective radius retrievals. As a result, the relatively large effective radius retrievals at $7.2^{\circ} \mathrm{N}$ from SEVIRI leads to a false alarm. Note that for a location of $\sim 7.2^{\circ} \mathrm{N}, \sim 7^{\circ} \mathrm{W}$ at $1400 \mathrm{UTC}$ on 24 th July, the sun was shining from the northwest with a zenith angle of $\sim 25^{\circ}$, and the satellite was viewing from the south with a zenith angle of $\sim 10^{\circ}$. This sun-viewing geometry along with a 
cumulus cloud type at $7^{\circ}-7.5^{\circ} \mathrm{N}$ likely introduces 'shadowing' effects in 3dimensional radiative transfer compared to its one-dimensional counterpart, leading to overestimated effective radii (Marshak et al., 2006). Therefore, the disagreements in rain detection between SEVIRI and MODIS can be caused not only by their different footprint sizes (i.e., sub-pixel cloud inhomogeneity), but also by the 3D variability at scales larger than their pixel sizes (e.g. Várnai and Marshak, 2002; Marshak et al., 2006; Wolters et al., 2010).

\subsection{Intercomparison of spatial distribution over Africa}

Expanding the single case study above, we now compare the occurrence frequency of warm rain between CloudSat/CALIPSO, SEVIRI and MODIS over Africa during June-September 2007-2010 at a spatial resolution of 2.5 (Fig. 6). The occurrence frequency is computed for each collocated dataset, defined as the ratio of warm rain occurrences to the total number of collocated observations. Warm rain occurrences from CloudSat/CALIPSO are calculated from warm clouds detected by the CloudSat/CALIPSO DARDAR product and 'rain certain' profiles from CloudSat 2C-PRECIP COLUMN product, whereas occurrences from SEVIRI and MODIS products are calculated using their own cloud phase retrieval (i.e., independent of DARDAR), and the optimal $E$ values listed in Table 2. As shown in Figure 6a, CloudSat/CALIPSO shows maximum warm rain frequencies between 5-10\% over the oceans and coastal regions of West Africa, East Africa and Madagascar. This spatial variability suggests that warm rain is strongly coupled with the maritime environment, and that the higher frequencies over coastal regions are linked to the inland movement of oceanic air 
by monsoon winds (Mülmenstädt et al., 2015). The coastal regions with frequent warm rain coincide with those with underestimated satellite rainfall estimates, e.g. over SWA (Nicholson et al., 2003) and Mozambique (Toté et al., 2015), highlighting the deficiency in current satellite rainfall retrievals that rely on the radiative signature of ice clouds.

The warm rain frequency from SEVIRI in Figure $6 \mathrm{~b}$ shows a similar spatial distribution to CloudSat/CALIPSO, which agrees particularly well over SWA but tends to misclassify and overestimate the frequency over inland Africa and the ocean towards higher latitudes. Warm rain frequency from MODIS in Figure 6c also has a similar spatial pattern, but in general the frequency is smaller than CloudSat/CALIPSO. Recall that the warm rain frequency from MODIS is determined by cloud phase and by the successful retrieval in cloud optical depth and effective radius. Figures $6 \mathrm{~d}$ and $6 \mathrm{f}$ show that MODIS detects a similar number of warm clouds to CloudSat/CALIPSO, but we found that MODIS fails to retrieve optical depth and effective radius for $28 \%$ of those warm clouds. As a result, warm rain frequency is underestimated by MODIS (Fig. 6c) compared to CloudSat/CALIPSO (Fig. 6a).

To examine the uncertainty in the warm rain frequencies, Figure 7 shows the frequency difference between those derived from the 5 th and 95 th percentiles of optimal $E$ (see Table 2). The frequency difference in warm rain frequency for SEVIRI and MODIS are similar, with a maximum of $2-2.5 \%$ over coastal regions. Overall, the relative uncertainty is small over ocean, but can be greater than $50 \%$ over land and coastal regions (Fig. 7c and 7d). 


\section{Daytime spatiotemporal distribution and variability of warm rain over southern West Africa}

Exploiting the 12-year long SEVIRI observations from 2004 to 2015 at 3-km resolution, we further examine the spatial and temporal distribution and variability of warm rain events. We focus on southern West Africa at $15^{\circ} \mathrm{W}-$ $10^{\circ} \mathrm{E}, 4^{\circ} \mathrm{N}-12^{\circ} \mathrm{N}$ (see Fig. 8) where warm rain occurs frequently as shown in Figure 6. This region is similar to the so-called Dynamics-Aerosol-ChemistryCloud Interactions in West Africa (DACCIWA) region used in Hill et al. (2016), but large enough to cover key topography such as Guinea Highlands, Jos Plateau and Cameroon Highlands. As shown later, it is crucial to include these highlands since warm rain frequency is strongly related to topography. Additionally, two types of frequency of warm rain occurrence will be discussed. One type is the conventional frequency of warm rain occurrence, defined as the ratio of the number of warm rain events to the total number of observations. For temporal statistics shown later, the denominator, the total number of observations, is then the total number of observations at the given time of day. The other type is socalled Probability Of Precipitation (POP), widely used in aerosol-cloud interaction studies, which is defined as the ratio of the number of warm rain events to the total number of warm cloud events.

\subsection{Seasonal cycle and interannual variability}


To fairly compare the seasonal cycle and interannual variability of warm rain events from SEVIRI with CloudSat observations over SWA, we examine SEVIRI observations between 1330 and 1430 UTC which are closest to the CloudSat overpass times between 1339 and 1422 UTC over the region. Since the entire SWA region presented in Figure 8 covers a substantial inland area, we investigate the seasonal cycle and interannual variability over the near-coastal region of $10^{\circ} \mathrm{W}-0^{\circ} \mathrm{E}, 4^{\circ} \mathrm{N}-8^{\circ} \mathrm{N}$, as warm rain is most frequent here in observations (Figure 6). Figure 9 shows that warm rain frequency has a marked seasonal cycle, predominating in the main monsoon season (June - September) and peaking in August. The warm rain annual cycles for SEVIRI and CloudSat/CALIPSO are generally in good agreement, although SEVIRI is slightly higher than CloudSat/CALIPSO in July and lower than CloudSat/CALIPSO in August, likely because of the different warm rain detection approaches used by the two sensors along with their different spatiotemporal sampling characteristics. This seasonal cycle of warm rain towards the coast contrasts with the bimodal seasonal cycle of rainfall over the region, which has a maximum in May then September-October (Le Barbé et al., 2002). Interestingly, the August maxima of warm rain concurs with a period of reduced rainfall during August, known as the 'little dry season' (e.g. Omotosho et al., 1988; Adejuwon and Odekunle, 2006). The 'little dry season' results from a suppression of convective activity by enhanced mid-tropospheric subsidence toward the coast (Omotosho et al., 1988). While convective activity and associated rainfall is reduced during this period, conditions are evidently favourable for warm rain as suggested by its August maximum frequency in Fig. 9. 
Figure 10 shows the interannual variability of warm rain frequency over SWA from SEVIRI observations. We examine interannual variability during August when warm rain is most frequent to avoid conflating months with different proportions of warm rain events, as shown by the seasonal cycle in Figure 9. Throughout August 2004-2015, the warm rain frequency from SEVIRI is relatively constant, with a mean frequency of $6.7 \%$ and a standard deviation of $1.2 \%$. The minimum frequency of $4.5 \%$ occurs in 2008 , closely followed by the maximum of $8.8 \%$ in 2009 . The overall variability is captured similarly by CloudSat/CALIPSO, although its frequencies are larger than SEVIRI during 2009 and 2010, which is also reflected by the 2007-2010 mean during August in Figure 9. Previous studies show that interannual variability in rainfall over SWA is closely linked to sea surface temperature variability in the Gulf of Guinea (e.g. Fontaine and Bigot, 1993; Odekunle and Eludoyin, 2008; Nguyen et al., 2011) and variability in the 'little dry season' (Adejuwon and Odekunle, 2006). Since warm rain persists during the August 'little dry season', factors driving the 'little dry season', such as the strength of the monsoon flow penetrating inland (Adejuwon and Odekunle, 2006), the proximity of highpressure over the Gulf of Guinea to the coast (Parker and Diop-Kane, 2017), and local sea surface temperatures (Odekunle and Eludoyin, 2008) may in turn influence warm rain variability at interannual scales. However, notably the interannual variability throughout the period shown in Figure 10 is relatively small and obtaining further insight into this variability over longer time periods is limited by the 12-year record of SEVIRI cloud property retrievals. In the future, it is hoped that new longer-term observations from SEVIRI will be 
available to be fully utilised to explore the factors controlling warm rain variability in detail.

\subsection{Diurnal cycle and spatiotemporal variability}

To help understand the spatiotemporal variability of warm rain, a high-resolution climatology of warm rain frequency observed by SEVIRI over SWA is presented in Figure 11. Overall, Figure 11 shows that warm rain events occur from the coast to inland as far north as $9^{\circ} \mathrm{N}$. In particular, warm rain is most frequent over mountainous regions in the morning and over coastal regions from late morning to early afternoon. Compared to the map in Figure 8, the spatial pattern of warm rain frequency is highly correlated with the local topography. Warm rain events are prominent on the southwest sides of the orography but almost entirely absent to the northeast, suggesting that warm rain formation is enhanced by orographic uplift. Such an enhancement is expected over SWA, as incident south-westerly monsoonal winds on mountain slopes assist warm cloud development, which is otherwise inhibited on leeward sides due to stable conditions (Schuster et al., 2013).

Over the coastal regions, the frequency of warm rain occurrence is particularly striking in the southwest along the Pepper Coast with maximum frequencies up to $20 \%$. Warm rain is also present at a lower frequency further east in bands between $7^{\circ} \mathrm{W}$ to $3^{\circ} \mathrm{W}$ along the Guinea Coast, and the western edge of the Niger Delta $\left(4^{\circ} \mathrm{E}\right.$ to $\left.7^{\circ} \mathrm{E}\right)$. During the morning, these coastal bands of warm rain move inland, increasing in frequency until dissipating during the 
afternoon. Similar inland movements of low-level stratus clouds are also observed over the region (van der Linden et al., 2015) and may be driven by local land-sea breeze fronts like those reported along southern West Africa (Cautenet and Rosset, 1989; Bajamgnigni-Gbambie and Steyn, 2013).

The pronounced differences in the diurnal cycle of warm rain frequency between the highland and coastal regions are highlighted in Figure 12. Over the Guinea Highlands, warm rain frequency reaches a maximum during the morning around 0900 UTC. After 0900 UTC the frequency decreases, likely related to the breakup of warm stratus into fair-weather cumulus at these northern latitudes (van der Linden et al., 2015). In contrast, warm rain frequencies over the Pepper Coast increase during the morning, simultaneously with the morning increase in solar insolation, reaching a maximum at 1245-1300 UTC. After midday, the frequency at the coast reduces during the afternoon. This coastal daytime variability presents further evidence of a land-sea breeze effect, whereby morning insolation creates a thermal and consequent pressure gradient between land and ocean, forcing cold, moist oceanic air toward warm rising air over land and encouraging cloud formation (Miller et al., 2003).

To further examine how likely it is for warm clouds over SWA to produce warm rain, Figure 13 shows the daytime climatology of POP. Warm clouds over Niger Delta and the coast from Guinea to Liberia have POP greater than $25 \%$ nearly throughout the entire day. Interestingly, although low clouds are prevailing at the Pepper Coast and Gold Coast from Ivory Coast to Benin, they have much lower POPs $(\sim 10 \%)$ compared to Niger Delta and Guinea Coast. In general, the 
POP of warm rain is lowest in inland, corroborating with Mülmenstädt et al. (2015). Understanding whether the differences in POP between regions are due to ambient aerosols or meteorological factors requires additional information on, e.g., aerosol properties and liquid water path. While evaluations of satellitebased aerosol products using the recent DACCIWA field campaign (Flamant et al., 2017) are in progress, the availability of a reliable dataset of LWP from satellite observations over SWA remains problematic. Nevertheless, such detailed spatial and temporal distributions of POP in Figure 13 are available for the first time, revealing a number of hot spots where further observations and investigation will greatly help identify the factors controlling the POP over SWA. The detailed distributions of POP can also be valuable for evaluating models as demonstrated next.

\section{Application to model evaluation of warm rain}

Capitalising on available high-resolution simulations generated by the Met Office Unified Model (MetUM, version 7.1) for the Cascade project (Pearson et al., 2010, 2013), we further demonstrate how SEVIRI-derived warm rain statistics can help evaluate model performance in diurnal behaviour and spatial distribution of low-level clouds. In this demonstration, we use the simulation at 4-km grid length as this has the closest spatial resolution to the SEVIRI retrievals. The simulation was run without a convection parameterisation scheme and was one-way nested in a $12-\mathrm{km}$ simulation with convection parameterisation; the 12-km simulation itself was both initialised and updated with boundary conditions derived from the European Centre for Medium-Range 
Weather Forecasts (ECMWF) analyses. This simulation will be referred to as the MetUM, and further details of the simulation are provided in Pearson et al. (2010, 2013).

Through evaluations of the MetUM simulation against CloudSat observations, Stein et al. (2015) found that the model produced too many low-level clouds, and that low-level cloud cover extended too far north. While these findings are informative about the model performance, they are inconclusive about POP because CloudSat only detects low-level clouds that are drizzling or associated with high liquid water contents (Lebsock and L'Ecuyer, 2011). Consequently, their evaluation results depend on not only the occurrence of low-level clouds, but also the accuracy of the modelled liquid water content. Using as many observations as available from various platforms is therefore invaluable to identify the source of the model deficiency.

As in Stein et al. (2015), the evaluation is restricted to 27 July to 3 August 2006, since hourly outputs of simulated 3D cloud fields were only available for 25 July to 3 August 2006, and the first two days are affected by model spin-up of clouds and convection. The cloud distributions for each hour are averaged over the simulation period for our analysis. For consistency with SEVIRI observations, we calculate the areal cloud fraction for model grid-box columns using a 'random-maximum' overlap assumption in the vertical to best represent cloud cover as seen from above. The low-level cloud fraction is then the difference between the areal cloud fraction at the surface and areal cloud fraction at the freezing level. Low-level clouds are only considered if the low-level cloud 
fraction is greater than 0.5 . While the choice of a low-level cloud fraction threshold is subjective, the focus of this analysis is only to demonstrate the potential application of this warm rain detection method for model evaluation. The best like-with-like comparison against SEVIRI could be achieved with forward simulating radiances from the model cloud fields, but this is beyond the scope of this study.

In Figure 14, warm cloud cover is shown for SEVIRI and MetUM simulations at different times of the day, averaged over the 8-day simulation period. The statistics have been calculated on the same regular $0.18^{\circ}$ grid (corresponding to $\sim 20 \mathrm{~km}$ at the equator) since the information at the pixel-level is too noisy when considering only 8 days. Note that we refer these statistics as 'cover' instead of 'frequency', due to our calculations on a coarser grid rather than the pixel level. For comparison against the findings of Stein et al. (2015), we focus on the 1300 UTC panels, although note that the following statements are also consistent for the other hours of the day. We note that, in the MetUM, warm cloud cover is greater than $50 \%$ across much of the Guinea coastal region and that values above $20 \%$ persist northward up to $12^{\circ} \mathrm{N}$, similar to the findings of Stein et al. (2015). Compared to SEVIRI, the spatial pattern of warm clouds in the west over Ivory Coast is represented well by the MetUM, although cloud cover is lower. In contrast, the cover in the east over Togo, Benin and Nigeria is typically higher in the MetUM than observed. However, Stein et al., (2015) found that across the region, the 4-km simulation produced less upper-level cloud than observed by CloudSat. This would explain the lower estimates of warm cloud cover from SEVIRI, since the presence of upper-level cloud will obscure some low-level 
clouds from these passive observations. Finally, the model underestimates warm cloud cover over ocean in the Gulf of Guinea by about a factor 2. While the Gulf of Guinea is close to the edge of the model domain, the lack of clouds in this region in the simulation could affect the monsoon dynamics through increased shortwave heating and decreased latent heating, as has been shown over land in SWA (e.g., Knippertz et al., 2011; Schrage and Fink, 2012; Birch et al., 2014).

For comparison to SEVIRI warm rain detection which is representative of 'rain certain' cases delineated by CloudSat using a threshold of $5 \mathrm{dBZ}$ at $1200 \mathrm{~m}$, we classify a grid box as a warm rain event if we have identified warm cloud and the surface rainfall rate in the grid box is greater than $3 \mathrm{~mm} \mathrm{~d}^{-1}$ as this corresponds approximately to a cloud base reflectivity of $5 \mathrm{dBZ}$ (Comstock et al., 2004). As shown in Figures 15-16, the spatial patterns of warm rain cover and POP averaged across the 8 days broadly match the pattern of warm cloud cover for both SEVIRI observations and the MetUM simulation. Compared to SEVIRI, the model evidently lacks warm rain over the Gulf of Guinea throughout the day and inland over Ivory coast in the morning at 0900 and 1100 UTC (Fig. 15). This lack of warm rain in the model is possibly due to the same model bias in warm cloud cover as shown in Figure 14. However, in the afternoon from 1300-1700 UTC, the model captures the warm rain cover along the Pepper Coast in the west, with a maximum approximately $100 \mathrm{~km}$ inland from the coast. In terms of the warm rain POP in Figure 16, the model compares reasonably well in magnitude to SEVIRI during the morning (0900 and 1100 UTC) in the east around the coast of Nigeria and Cameroon, and during the afternoon (1500 UTC) in the west along the coast of Ivory Coast. However, the simulated POP is 
generally too low north of the Guinea coast inland across Ivory Coast, Ghana, Benin and Togo and sometimes locally too high in the west over Liberia.

Recall that the evaluations against CloudSat observations in Stein et al. (2015) reveal that the majority of low-level clouds in the model have relatively high simulated radar reflectivity, suggesting high liquid water contents or drizzle. However, the current evaluations against the SEVIRI observations shows that the majority of warm clouds have low probability of precipitation, in contrast with the conclusion from interpreting radar reflectivity alone. For further insight into warm-rain processes, model evaluation studies need to consider multi-instrument and multi-simulator approaches, which can investigate whether observed relationships between, e.g., radar reflectivity and microwave radiances are reproduced by model simulations.

Finally, it should be highlighted that the MetUM simulation evaluated here is specific to the region of West Africa, the 8-day simulation period and this particular model configuration. Thus, any conclusions drawn for MetUM simulations for other regions, periods and model configurations could be quite different.

\section{Summary and conclusions}

Given the prevailing warm cloud cover and misrepresentation of rainfall by satellite rainfall estimates over SWA, we have presented a new method for delineating warm rain using geostationary-based shortwave cloud property 
retrievals from SEVIRI to understand the spatiotemporal variability of warm rain events during the monsoon. The method combines daytime retrievals of cloud optical depth and effective radius from SEVIRI to detect the occurrence of warm rain, assuming that warm rain occurs when the effective radius exceeds a critical threshold for a given optical depth and coefficient $E$. The coefficient $E$ is empirically optimised using a collocated dataset of SEVIRI cloud retrievals with CALIPSO and CloudSat which provide detailed information on cloud boundaries and the presence of precipitating rain drops.

We have found that an optimal coefficient $E$ of $480 \mu \mathrm{m}$ with an uncertainty range of $440-510 \mu \mathrm{m}$ applied to SEVIRI retrievals maximises warm rain detection skill with an HSS of 0.39 (uncertainty range of $0.37-0.40$ ) over land, with uncertainty estimated by a $90 \%$ confidence interval from bootstrap resampling. The skill scores from SEVIRI are comparable with those from MODIS that has the best-collocated retrievals with CloudSat observations due to its same orbit with CloudSat in the A-Train satellite constellation. Overall, the results from both passive sensors show that warm rain detections perform better over ocean than over land, and that clouds over land require more total water content to precipitate.

Capitalising on the high spatiotemporal resolution and 12-year record of SEVIRI observations, we examine the seasonal and diurnal cycle, and interannual and spatial variability of warm rain events over SWA. We have found that warm rain has a unimodal seasonal cycle, peaking in August during the monsoon. Additionally, warm rain frequency is rather consistent throughout 
the 12-year record and does not show significant year-to-year variability. The hourly daytime SEVIRI climatology over SWA during June-September 20042015 shows that warm rain is most frequent over orographic regions in the morning (0900 UTC) and coastal regions around midday (1200-1300 UTC), with the highest probability of precipitation along coastlines and the lowest inland. These diurnal and spatial variations indicate that warm rain processes are strongly linked to orographic lifting and coastal land-sea breezes. Since these regions of frequent warm rain coincide with those with pronounced underestimation in cold-cloud based satellite rainfall estimates, this new geostationary detection method can help provide an added-value flag highlighting periods and areas experiencing persistent warm rain.

The high spatial and temporal resolution of warm rain detection from SEVIRI also provides a new opportunity to evaluate the representation of warm rain in weather and climate models. Compared to SEVIRI observations, we have found that 4-km resolution simulations from the MetUM during 27 July-3 August 2006 over SWA captured the spatial pattern and magnitude of warm rain frequency and warm rain probability, showing highest frequencies along the Guinea Coast and highest probability along the coast of Nigeria. However, simulated warm cloud cover and thus warm rain frequencies were too low over the Gulf of Guinea, and probability was too low further inland.

Although this method greatly improves the monitoring of warm rain frequency, detecting warm rain at nighttime and estimating warm rain amount remains a challenge. Further research is required to resolve the full diurnal cycle 
of warm rain, and to quantify the contribution of warm rain to the hydrological

cycle. For southern West Africa, it is hoped that new ground-based observations from the DACCIWA field campaign will help to tackle these areas and understand the role of warm rain in the West African monsoon system.

\section{Acknowledgments}

The research leading to this publication has been supported by a NERC (Natural Environment Research Council) Ph.D. studentship and the European Union 7th Framework Programme (FP7/2007-2013) under grant agreement 603502 (EU project DACCIWA: Dynamics-Aerosol- Chemistry-Cloud Interactions in West Africa). MY and EB acknowledge support from the Natural Environment Research Council, the climate division of the National Centre for Atmospheric Science and the Global Challenges Research Fund, via Atmospheric hazard in developing Countries: Risk assessment and Early Warning (ACREW)

[NE/R000034/1]. 


\section{References}

Adejuwon JO, Odekunle TO. 2006. Variability and the Severity of the "Little

Dry Season" in Southwestern Nigeria. J. Clim., 19, 483-493, DOI:

10.1175/JCLI3642.1.

Albrecht BA. 1989. Aerosols, cloud microphysics, and fractional

cloudiness. Science, 245: 1227-1230. DOI: 10.1126/science.245.4923.1227.

Anselmo T, Clifton R, Hunt W, Lee K, Murray T, Powell K, Chomette O,

Viollier M, Garnier A, Pelon J. 2006. Cloud-Aerosol LIDAR Infrared Pathfinder

Satellite Observations (CALIPSO). In Data Management System and Data

Products Catalog, Doc. PC-SCI-503. NASA, Hampton, Va.

Bajamgnigni-Gbambie AS, Steyn DG. 2013. Sea breezes at Cotonou and their interaction with the West African monsoon. Int. J. Climatol., 33, 28892899. DOI: $10.1002 /$ joc.3637.

Barnston AG. 1992. Correspondence among the Correlation, RMSE, and Heidke Forecast Verification Measures; Refinement of the Heidke Score. Wea. Forecasting, 7, 699-709. DOI: 10.1175/1520-

0434(1992)007<0699:CATCRA>2.0.CO;2.

Benas N, Finkensieper S, Stengel M, van Zadelhoff G-J, Hanschmann T, Hollmann R, Meirink JF. 2017. The MSG-SEVIRI-based cloud property data 
record CLAAS-2. Earth Syst. Sci. Data, 9, 415-434. DOI: 10.5194/essd-9-4152017.

Birch CE, Parker DJ, Marsham JH, Copsey D, Garcia-Carreras L. 2014. A seamless assessment of the role of convection in the water cycle of the West African Monsoon. J. Geophys. Res. Atmos., 119, 2890-2912. DOI: 10.1002/2013JD020887.

Bouniol D, Couvreux F, Kamsu-Tamo P, Leplay M, Guichard F, Favot F, O’Connor EJ. 2012. Diurnal and Seasonal Cycles of Cloud Occurrences, Types, and Radiative Impact over West Africa. J. Appl. Meteor. Climatol., 51, 534-553. DOI: 10.1175/JAMC-D-11-051.1

Cautenet S, Rosset R. 1989. Numerical Simulation Of Sea Breezes with Vertical Wind Shear during Dry Season at Cape of Three Points, West Africa. Mon. Wea. Rev., 117, 329-339. DOI: 10.1175/15200493(1989)117<0329:NSOSBW>2.0.CO;2.

Ceccaldi M, Delanoë J, Hogan RJ, Pounder NL, Protat A, Pelon J. 2013. From CloudSat-CALIPSO to EarthCare: Evolution of the DARDAR cloud classification and its comparison to airborne radar-lidar observations. $J$. Geophys. Res. Atmos., 118, 7962-7981. DOI: 10.1002/jgrd.50579.

Chen Y, Fu Y. 2016. Characteristics of VIRS Signals within Pixels of TRMM PR for Warm Rain in the Tropics and Subtropics. J. Appl. Meteor. Climatol., 
56, 789-801. DOI: 10.1175/JAMC-D-16-0198.1.

Chen R, Li Z, Kuligowski RJ, Ferraro R, Weng F. 2011. A study of warm rain detection using A-Train satellite data. Geophys. Res. Lett., 38, L04804. DOI: 10.1029/2010GL046217.

Chiu JC, Holmes JA, Hogan RJ, O'Connor EJ. 2014. The interdependence of continental warm cloud properties derived from unexploited solar background signals in ground-based lidar measurements. Atmos. Chem. Phys., 14, 83898401. DOI: $10.5194 / \mathrm{acp}-14-8389-2014$.

Cho H-M, Zhang Z, Meyer K, Lebsock M, Platnick S, Ackerman AS, Di Girolamo L, C-Labonnote L, Cornet C, Riedi J, Holz RE. 2015. Frequency and causes of failed MODIS cloud property retrievals for liquid phase clouds over global oceans. J. Geophys. Res. Atmos., 120, 4132-4154. DOI:

10.1002/2015JD023161.

Comstock KK, Wood R, Yuter SE, Bretherton, CS. 2004. Reflectivity and rain rate in and below drizzling stratocumulus. Q.J.R. Meteorol. Soc., 130: 28912918. DOI:10.1256/qj.03.187.

Cook KH, Vizy EK. 2006. Coupled model simulations of the West African monsoon system: 20 th century simulations and 21 st century predictions, J. Clim., 19, 3681-3703. DOI: 10.1175/JCLI3814.1. 
Christensen MW, Stephens GL, Lebsock MD. 2013. Exposing biases in retrieved low cloud properties from CloudSat: A guide for evaluating observations and climate data. J. Geophys. Res. Atmos., 118, 12,120-12,131. DOI:

10.1002/2013JD020224.

Delanoë J, Hogan RJ. 2010. Combined CloudSat-CALIPSO-MODIS retrievals of the properties of ice clouds. J. Geophys. Res., 115, D00H29. DOI:

10.1029/2009JD012346.

Dunning CM, Allan RP, E Black. 2017. Identification of deficiencies in seasonal rainfall simulated by CMIP5 climate models. Environ. Res. Lett., 12, 114001. DOI: $10.1088 / 1748-9326 /$ aa869e.

Ellis TD, L'Ecuyer T, Haynes JM, Stephens GL. 2009. How often does it rain over the global oceans? The perspective from CloudSat. Geophys. Res. Lett., 36, L03815. DOI: 10.1029/2008GL036728.

Fielding MD, Chiu JC, Hogan RJ, Feingold G, Eloranta E, O'Connor EJ, Cadeddu MP. 2015. Joint retrievals of cloud and drizzle in marine boundary layer clouds using ground-based radar, lidar and zenith radiances. Atmos. Meas. Tech., 8, 2663-2683. DOI: 10.5194/amt-8-2663-2015.

Flamant C, Knippertz P, Fink AH, Akpo A, Brooks B, Chiu JC, Coe H, Danuor S, Evans M, Jegede O, Kalthoff N, Konaré A, Liousse C, Lohou F, Mari C, Schlager H, Schwarzenboeck A, Adler B, Amekudzi L, Aeyee J, Ayoola M, 
Batenburg AM, Bessardon G, Borrmann S, Brito J, Bower K, Burnet F, Catoire V, Colomb A, Denjean C, Fosu-Amankwah K, Hill PG, Lee J, Lothon M, Maranan M, Marsham J, Meynadier R, Ngamini J-B, Rosenberg P, Sauer D, Smith V, Stratmann G, Taylor JW, Voigt C, Yoboue V, 2017: The DynamicsAerosol-Chemistry-Cloud Interactions in West Africa field campaign: Overview and research highlights, Bull. Amer. Meteor. Soc., doi:10.1175/BAMS-D-160256.1, in press.

Fontaine B, Bigot S. 1993. West African rainfall deficits and sea surface temperatures. Int. J. Climatol., 13: 271-285. DOI:10.1002/joc.3370130304.

Fuentes JD, Geerts B, Dejene T, D’Odorico P, Joseph E. 2008. Vertical attributes of precipitation systems in West Africa and adjacent Atlantic Ocean. Theor. Appl. Climatol., 92, 181-193. DOI: 10.1007/s00704-007-0318-0.

Haynes JM, L'Ecuyer TS, Stephens GL, Miller SD, Mitrescu C, Wood NB, Tanelli S. 2009. Rainfall retrieval over the ocean with spaceborne W-band radar. J. Geophys. Res., 114, D00A22, DOI: 10.1029/2008JD009973.

Hill PG, Allan RP, Chiu JC, Stein THM. 2016. A multisatellite climatology of clouds, radiation, and precipitation in southern West Africa and comparison to climate models. J. Geophys. Res. Atmos., 121, 10,857-10,879, DOI:10.1002/2016JD025246. 
King MD, Menzel WP, Kaufman YJ, Tanré D, Gao BC, Platnick S, Hubanks, PA. 2003. Cloud and aerosol properties, precipitable water, and profiles of temperature and water vapor from MODIS. IEEE Transactions on Geoscience and Remote Sensing, 41(2), 442-458, DOI: 10.1109/TGRS.2002.808226.

Knippertz P, Fink AH, Schuster R, Trentmann J, Schrage JM, and Yorke C, 2011: Ultra-low clouds over the southern West African monsoon region, Geophys. Res. Lett., 38, L21808, DOI:10.1029/2011GL049278.

Knippertz P, Evans M, Field PR, Fink AH, Liousse C, Marsham JH. 2015. The possible role of local air pollution in climate change in West Africa. Nature Clim. Change, DOI: 10.1038/NCLIMATE2727.

Kummerow C, Barnes W, Kozu T, Shiue J, Simpson J. 1998. The tropical rainfall measuring mission (TRMM) sensor package. J. Atmos. Oceanic Tech., 15, 809-817. DOI: 10.1175/15200426(1998)015<0809:TTRMMT>2.0.CO;2.

Le Barbé L, Lebel T, Tapsoba D. 2002. Rainfall Variability in West Africa during the Years 1950-90. J. Clim., 15, 187-202, DOI: 10.1175/15200442(2002)015<0187:RVIWAD>2.0.CO;2

Lebsock MD and T. S. L'Ecuyer, 2011: The retrieval of warm rain from CloudSat. J. Geophys. Res. Atmos., 116, D20209. DOI:

10.1029/2011JD016076. 
Lebsock MD, Stephens GL, Kummerow C. 2008. Multisensor satellite observations of aerosol effects on warm clouds. J. Geophys. Res., 113, D15205. DOI: 10.1029/2008JD009876.

Lensky IM, Rosenfeld D. 1997. Estimation of Precipitation Area and Rain Intensity Based on the Microphysical Properties Retrieved from NOAA AVHRR Data. J. Appl. Meteor., 36, 234-242. DOI: 10.1175/1520-

0450(1997)036<0234:EOPAAR>2.0.CO.

Liu C, Zipser EJ. 2009: "Warm rain" in the tropics: Seasonal and regional distributions based on $9 \mathrm{yr}$ of TRMM data. J. Clim., 22, 767-779. DOI: 10.1175/2008JCLI2641.1.

Mann JAL, Chiu JC, Hogan RJ, O'Connor EJ, L'Ecuyer TS, Stein THM, Jefferson A. 2014. Aerosol impacts on drizzle properties in warm clouds from ARM Mobile Facility maritime and continental deployments. J. Geophys. Res. Atmos., 119, 4136-4148. DOI: 10.1002/2013JD021339.

Marchand R, Mace GG, Ackerman T, Stephens G. 2008. Hydrometeor detection using CloudSat - An earth-orbiting 94-GHz cloud radar. J. Atmos. Oceanic Tech., 25, 519-533. DOI: 10.1175/2007JTECHA1006.1. 
Marchant B, Platnick S, Meyer K, Arnold GT, Riedi J. 2016. MODIS Collection 6 shortwave-derived cloud phase classification algorithm and comparisons with CALIOP. Atmos. Meas. Tech., 9, 1587-1599. DOI: 10.5194/amt-9-1587-2016.

Marshak A, Platnick S, Várnai T, Wen G, Cahalan RF. 2006. Impact of threedimensional radiative effects on satellite retrievals of cloud droplet sizes. $J$. Geophys. Res., 111, D09207. DOI: 10.1029/2005JD006686.

Miller STK, Keim BD, Talbot RW, Mao H. 2003. Sea breeze: Structure, forecasting, and impacts. Rev. Geophys., 41, 1011. DOI: 10.1029/2003RG000124.

Mülmenstädt J, Sourdeval O, Delanoë J, Quaas J. 2015. Frequency of occurrence of rain from liquid-, mixed-, and ice-phase clouds derived from A-Train satellite retrievals. Geophys. Res. Lett., 42, 6502-6509. DOI: 10.1002/2015GL064604.

Nakajima T, King MD. 1990. Determination of the optical thickness and effective particle radius of clouds from reflected solar radiation measurements. Part I: Theory. J. Atmos. Sci., 47, 1878-1893. DOI: 10.1175/15200469(1990)047<1878:DOTOTA>2.0.CO;2.

Nakajima TY, Suzuki K, Stephens GL. 2010. Droplet Growth in Warm Water Clouds Observed by the A-Train. Part II: A Multisensor View. J. Atmos. Sci., 67, 1897-1907. DOI: 10.1175/2010JAS3276.1. 
Nauss T, Kokhanovsky A. 2006. Discriminating raining from non-raining clouds at mid- latitudes using multispectral satellite data. Atmos. Chem. Phys., 6, 50315036. DOI: 10.5194/acp-6-5031-2006.

Nguyen H, Thorncroft CD, Zhang C. 2011. Guinean coastal rainfall of the West African Monsoon. Q.J.R. Meteorol. Soc., 137: 1828-1840. DOI:10.1002/qj.867.

Nicholson SE. 2001. Climatic and environmental change in Africa during the last two centuries. Clim. Research, 17(2), pp.123-144. DOI: 10.3354/cr017123.

Nicholson SE, Some B, McCollum J, Nelkin E, Klotter D, Berte Y, Diallo BM, Gaye I, Kpabeba G, Ndiaye O, Noukpozounkou JN, Tanu MM, Thiam A, Toure AA, Traore AK. 2003. Validation of TRMM and Other Rainfall Estimates with a High-Density Gauge Dataset for West Africa. Part II: Validation of TRMM Rainfall Products. J. Appl. Meteor., 42, 1355-1368. DOI: 10.1175/15200450(2003)042<1337:VOTAOR>2.0.CO;2.

Odekunle TO, Eludoyin AO. 2008. Sea surface temperature patterns in the Gulf of Guinea: their implications for the spatio-temporal variability of precipitation in West Africa. Int. J. Clim., 28:1507-17.

Omotosho J. 1988. Spatial variation of rainfall in Nigeria during the "little dry season”, Atmos. Res., 22, 137-147. DOI: 10.1016/0169-8095(88)90004-X 
Painemal D, Chiu J-YC, Minnis P, Yost C, Zhou X, Cadeddu M, Eloranta E, Lewis ER, Ferrare R, Kollias P. 2017. Aerosol and cloud microphysics covariability in the northeast Pacific boundary layer estimated with ship-based and satellite remote sensing observations, J. Geophys. Res. Atmos., 122, 24032418, DOI:10.1002/2016JD025771.

Painemal D, Zuidema P. 2011. Assessment of MODIS cloud effective radius and optical thickness retrievals over the Southeast Pacific with VOCALS REx in situ measurements. Journal of Geophysical Research: Atmospheres, 116, D24206. DOI:10.1029/2011JD016155.

Parker DJ, Diop-Kane M (eds.). 2017. Meteorology of Tropical West Africa: The Forecaster's Handbook. Wiley - Blackwell: Oxford, UK.

Pearson KJ, Hogan RJ, Allan RP, Lister GMS, Holloway CE. 2010. Evaluation of the model representation of the evolution of convective systems using satellite observations of outgoing longwave radiation. J. Geophys.

Res., 115, D20206, DOI: 10.1029/2010JD014265.

Pearson KJ, Lister GMS, Birch CE, Allan RP, Hogan RJ and Woolnough SJ. 2013: Modelling the diurnal cycle of tropical convection across the 'grey zone'. Q.J.R. Meteorol. Soc., 140: 491-499. DOI:10.1002/qj.2145. 
Petty GW. 1999. Prevalence of Precipitation from Warm-Topped Clouds over Eastern Asia and the Western Pacific. J. Clim., 12, 220-229. DOI: 10.1175/15200442(1999)012<0220:POPFWT>2.0.CO;2.

Platnick S, King MD, Ackerman SA, Menzel WP, Baum BA, Riédi JC, Frey RA. 2003. The MODIS cloud products: Algorithms and examples from Terra. IEEE Transactions on Geoscience and Remote Sensing, 41(2), 459-473. DOI: 10.1109/TGRS.2002.808301.

Platnick S, Meyer KG, King MD, Wind G, Amarasinghe N, Marchant B, Arnold GT, Zhang Z, Hubanks PA, Holz RE, Yang P. 2017. The MODIS cloud optical and microphysical products: Collection 6 updates and examples from Terra and Aqua. IEEE Transactions on Geoscience and Remote Sensing, 55(1), 502-525. DOI: 10.1109/TGRS.2016.2610522.

Roebeling RA, Feijt AJ, Stammes P. 2006. Cloud property retrievals for climate monitoring: Implications of differences between Spinning Enhanced Visible and Infrared Imager (SEVIRI) on METEOSAT-8 and Advanced Very High Resolution Radiometer (AVHRR) on NOAA-17. J. Geophys. Res., 111, D20210. DOI: 10.1029/2005JD006990.

Roebeling RA, Holleman I. 2009. SEVIRI rainfall retrieval and validation using weather radar observations. J. Geophys. Res., 114, D21202. DOI: 10.1029/2009JD012102. 
Roehrig R, Bouniol D, Guichard F, Hourdin F, Redelsperger J-L. 2013. The present and future of the West African monsoon: a process-oriented assessment of CMIP5 simulations along the AMMA transect. J. Clim., 26, 6471-6505. DOI: 10.1175/JCLI-D-12-00505.1.

Rosenfeld D, Cattani E, Melani S, Levizzani V, 2004. CONSIDERATIONS ON DAYLIGHT OPERATION OF 1.6-VERSUS 3.7- $\mu \mathrm{m}$ CHANNEL ON NOAA AND METOP SATELLITES. Bull. Amer. Meteor. Soc., 85, 873-882, DOI: 10.1175/BAMS-85-6-873.

Rosenfeld D, Gutman G. 1994. Retrieving microphysical properties near the tops of potential rain clouds by multispectral analysis of AVHRR data. Atmos. Res., 34, 259-283. DOI: 10.1016/0169-8095(94)90096-5.

Rosenfeld D, Rudich Y, Lahav R. 2001. Desert dust suppressing precipitation: A possible desertification feedback loop. Proc. Nat. Academy Sci., 98, 59755980. DOI: 10.1073/pnas.101122798.

Schmetz J, Pili P, Tjemkes S, Just D, Kerkmann J, Rota S, Ratier A. 2002. An Introduction to Meteosat Second Generation (MSG). Bull. Amer. Meteor. Soc., 83,977-992. DOI: 10.1175/1520-0477(2002)083<0977:AITMSG>2.3.CO;2.

Schrage JM, Augustyn S, Fink AH. 2007. Nocturnal stratiform cloudiness during the West African monsoon. Meteor. Atmos. Phys., 95, 73-86. DOI:

10.1007/s00703-006-0194-7. 
Schrage JM, Fink AH. 2012. Nocturnal continental low-level stratus over tropical West Africa: observations and possible mechanisms controlling its onset. Mon. Wea. Rev., 140, 1794-1809. DOI: 10.1175/MWR-D-11-00172.1.

Schumacher C, Houze RA. 2006. Stratiform precipitation production over subSaharan Africa and the tropical East Atlantic as observed by TRMM. Q. J. R. Met. Soc., 132, 2235-2255. DOI: 10.1256/qj.05.121.

Schuster R, Fink AH, Knippertz P. 2013. Formation and maintenance of nocturnal low-level stratus over the southern West African monsoon region during AMMA 2006. J. Atmos. Sci., 70, 2337-2355. DOI: 10.1175/JAS-D-120241.1.

Sealy A, Jenkins GS, Walford SC. 2003. Seasonal/regional comparisons of rain rates and rain characteristics in West Africa using TRMM observations. J. Geophys. Res., 108, 4306. DOI: 10.1029/2002JD002667.

Smalley M, L'Ecuyer T, Lebsock M, Haynes J. 2014. A Comparison of Precipitation Occurrence from the NCEP Stage IV QPE Product and the CloudSat Cloud Profiling Radar. J. Hydrometeor., 15, 444-458. DOI: 10.1175/JHM-D-13-048.1.

Stein THM, Parker DJ, Delanoë J, Dixon NS, Hogan RJ, Knippertz P, Maidment RI, Marsham JH. 2011. The vertical cloud structure of the West African 
monsoon: a 4 year climatology using CloudSat and CALIPSO. J. Geophys. Res., 116, D22205. DOI: 10.1029/2011JD016029.

Stein THM, Parker DJ, Hogan RJ, Birch CE, Holloway CE, Lister GMS, Marsham, JH, Woolnough SJ. 2015. The representation of the West African monsoon vertical cloud structure in the Met Office Unified Model: an evaluation with CloudSat. Q.J.R. Meteorol. Soc., 141: 3312-3324. DOI: 10.1002/qj.2614.

Stephens GL. 1978. Radiation Profiles in Extended Water Clouds. II: Parameterization Schemes. J. Atmos. Sci., 35, 2123-2132. DOI: 10.1175/15200469(1978)035<2123:RPIEWC >2.0.CO;2

Stephens G, Vane D, Boain R, Mace G, Sassen K, Wang Z, Illingworth A, O’Connor E, Rossow W, Durden S, Miller S, Austin R, Benedetti A, Mitrescu C, the CloudSat Science Team. 2002. The CloudSat mission and the A-train: a new dimension of space-based observations of clouds and precipitation. Bull. Amer. Met. Soc., 83, 1771-1790. DOI: 10.1175/BAMS-83-12-1771.

Suzuki K, Nakajima T, Stephens GL. 2010. Particle Growth and Drop Collection Efficiency of Warm Clouds as Inferred from Joint CloudSat and MODIS Observations. J. Atmos. Sci., 67, 3019-3032. DOI: 10.1175/2010JAS3463.1.

Tanelli S, Durden SL, Im E, Pak KS, Reinke DG, Partain P, Haynes JM, Marchand RT, 2008. CloudSat's cloud profiling radar after two years in orbit: 
Performance, calibration, and processing. IEEE Trans. Geosci. Remote Sens., 46, 3560-3573. DOI: 10.1109/TGRS.2008.2002030.

Toté C, Patricio D, Boogaard H, van der Wijngaart R, Tarnavsky E, Funk C. 2015. Evaluation of Satellite Rainfall Estimates for Drought and Flood Monitoring in Mozambique. Remote Sensing. 7(2):1758-1776.

DOI:10.3390/rs70201758.

Tucker MR, Sear CB. 2001. A comparison of Meteosat rainfall estimation techniques in Kenya. Met. Apps., 8: 107-117. DOI:

$10.1017 / \mathrm{S} 1350482701001098$.

van der Linden R, Fink AH, Redl R. 2015. Satellite-based climatology of lowlevel continental clouds in southern West Africa during the summer monsoon season. J. Geophys. Res. Atmos., 120, 1186-1201. DOI: 10.1002/2014JD022614.

vanZanten MC, Stevens B, Vali G, Lenschow DH. 2005. Observations of Drizzle in Nocturnal Marine Stratocumulus. J. Atmos. Sci., 62, 88-106. DOI:

10.1175/JAS-3355.1.

Várnai T, Marshak A. 2002. Observations of Three-Dimensional Radiative Effects that Influence MODIS Cloud Optical Thickness Retrievals. J. Atmos. Sci., 59, 1607-1618. DOI: 10.1175/15200469(2002)059<1607:OOTDRE>2.0.CO;2. 
Vellinga M, Arribas A, Graham R. 2013. Seasonal forecasts for regional onset of the West African monsoon. Climate Dynamics. 40, 11-12, 30473070. DOI: 10.1007/s00382-012-1520-z.

Wang M, Ghan S, Liu X, L'Ecuyer TS, Zhang K, Morrison H, Ovchinnikov M, Easter R, Marchand R, Chand D, Qian Y, Penner JE. 2012. Constraining cloud lifetime effects of aerosols using A-Train satellite observations. Geophys. Res. Lett., 39, L15709. DOI: 10.1029/2012GL052204.

Washington R, Kay G, Harrison M, Conway D, Black E, Challinor A, Grimes D, Jones R, Morse A, Todd M. 2006. African Climate Change: Taking the Shorter Route. Bull. Amer. Meteor. Soc., 87, 1355-1366. DOI: 10.1175/BAMS-87-101355.

Winker D, Vaughan M, Omar A, Hu Y, Powell K, Liu Z, Hunt W, Young S. 2009. Overview of the CALIPSO Mission and CALIOP Data Processing Algorithms. J. Atmos. Oceanic Technol., 26, 2310-2323. DOI: 10.1175/2009JTECHA1281.1.

Wood R. 2005. Drizzle in Stratiform Boundary Layer Clouds. Part I: Vertical and Horizontal Structure. J. Atmos. Sci., 62, 3011-3033. DOI:

10.1175/JAS3529.1. 
Wood R, Hartmann DL. 2006. Spatial Variability of Liquid Water Path in Marine Low Cloud: The Importance of Mesoscale Cellular Convection. J. Clim., 19, 1748-1764. DOI: 10.1175/JCLI3702.1.

Wood R, Mechoso, CR, Bretherton CS, Weller RA, Huebert B, Straneo F, Albrecht BA, Coe H, Allen G, Vaughan G, Daum P, Fairall C, Chand D, Gallardo Klenner L, Garreaud R, Grados C, Covert DS, Bates TS, Krejci R, Russell LM, de Szoeke S, Brewer A, Yuter SE, Springston SR, Chaigneau A, Toniazzo T, Minnis P, Palikonda R, Abel SJ, Brown WOJ, Williams S, Fochesatto J, Brioude J, Bower KN. 2011. The VAMOS Ocean-CloudAtmosphere-Land Study Regional Experiment (VOCALS-REX): Goals, platforms, and field operations. Atmos. Chem. Phys., 11, 627-654. DOI: 10.5194/acp-11-627-2011.

Young MP, Williams CJR, Chiu JC, Maidment RI, Chen S-H. 2014. Investigation of Discrepancies in Satellite Rainfall Estimates over Ethiopia. $J$. Hydrometeor., 15, 2347-2369. DOI: 10.1175/JHM-D-13-0111.1. 


\section{List of Tables}

Table 1. Contingency table used to evaluate the skill of warm rain detection from passive satellite observations, using warm rain events detected by CloudSat observations as a reference. A-D represent the number of hits, false alarms, misses and correct negatives, respectively.

\begin{tabular}{c|cc} 
& \multicolumn{2}{|c}{ Detected by CloudSat } \\
Detected by passive satellite observation & Yes & No \\
\hline Yes & A & B \\
No & C & D
\end{tabular}


Table 2. A summary of the median and the range for the optimized coefficient $E$ and Heidke Skill Score (HSS), derived from SEVIRI and MODIS retrievals over land and ocean during June-September 2007-2010. The range represents the 90\% confidence intervals computed from bootstrap resampling of the dataset 1000 times. These values are provided for warm rain delineation using the 'rain possible' and 'rain certain' precipitation flags, defined by radar reflectivity thresholds as listed, from CloudSat 2C-PRECIP-COLUMN products. 


\begin{tabular}{|c|c|c|c|c|c|c|c|c|}
\hline & \multicolumn{4}{|c|}{ SEVIRI } & \multicolumn{4}{|c|}{ MODIS } \\
\hline & \multicolumn{2}{|c|}{$\underline{\text { Coefficient } E(\mu \mathrm{m})}$} & \multicolumn{2}{|c|}{$\underline{\mathrm{HSS}}$} & \multicolumn{2}{|c|}{$\underline{\text { Coefficient } E(\mu \mathrm{m})}$} & \multicolumn{2}{|c|}{$\underline{\mathrm{HSS}}$} \\
\hline & Median & Range & Median & Range & Median & Range & Median & Range \\
\hline Land & & & & & & & & \\
\hline $\begin{array}{l}\text { Rain certain } \\
\text { (Reflectivity }>5 \mathrm{dBZ} \text { ) }\end{array}$ & 480 & $440-510$ & 0.39 & $0.37-0.40$ & 510 & $490-600$ & 0.31 & $0.29-0.32$ \\
\hline $\begin{array}{l}\text { Rain possible } \\
\text { (Reflectivity }>-5 \mathrm{dBZ} \text { ) }\end{array}$ & 450 & $420-480$ & 0.40 & $0.38-0.41$ & 510 & $460-560$ & 0.32 & $0.30-0.33$ \\
\hline Ocean & & & & & & & & \\
\hline $\begin{array}{l}\text { Rain certain } \\
\text { (Reflectivity }>0 \mathrm{dBZ} \text { ) }\end{array}$ & 350 & $330-350$ & 0.47 & $0.47-0.48$ & 380 & $360-390$ & 0.45 & $0.45-0.46$ \\
\hline $\begin{array}{l}\text { Rain possible } \\
(\text { Reflectivity }>-15 \mathrm{dBZ})\end{array}$ & 200 & $190-200$ & 0.55 & $0.55-0.55$ & 230 & $220-240$ & 0.54 & $0.53-0.54$ \\
\hline
\end{tabular}

This article is protected by copyright. All rights reserved. 


\section{List of Figures}

(a) Optical depth, Land

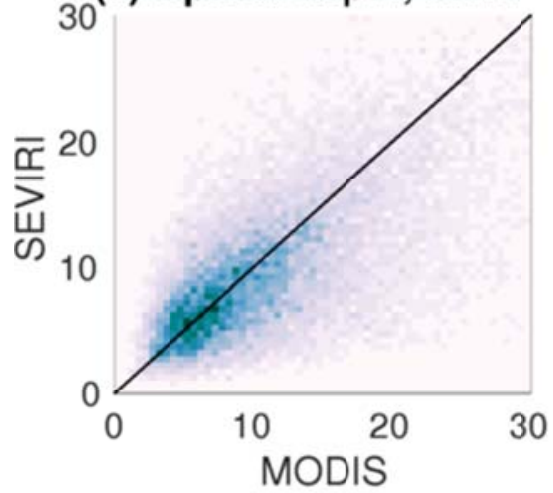

(c) Effective radius, Land
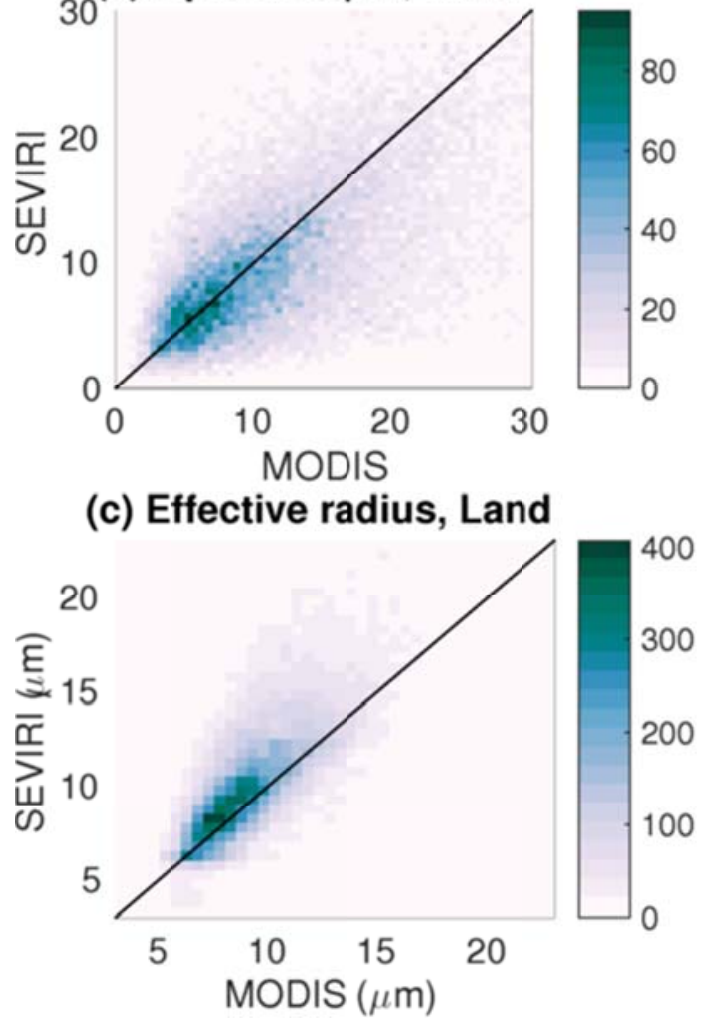

(b) Optical depth, Ocean

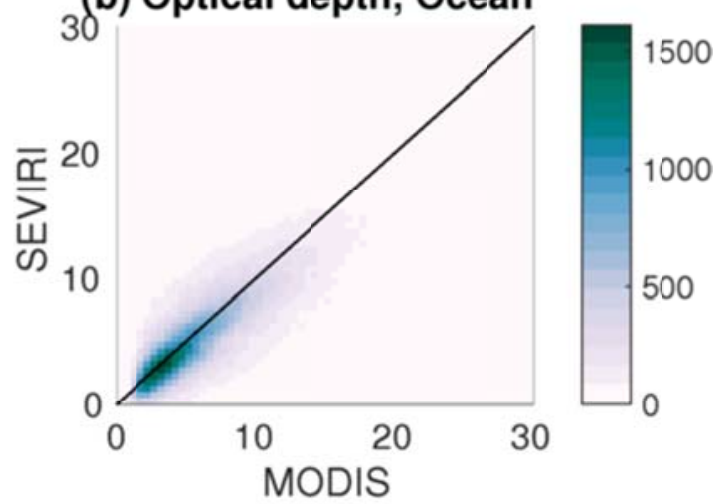

(d) Effective radius, Ocean

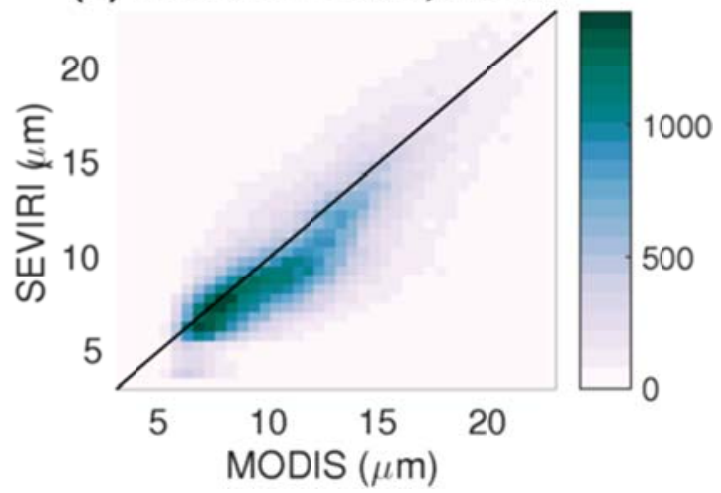

Figure 1. Joint histograms (in counts) comparing collocated warm cloud retrievals from MODIS and SEVIRI of $(a, b)$ optical depth and (c, d) cloud effective radius $(\mu \mathrm{m})$ over land and ocean. The wavelength of the MODIS effective radius retrieval is $2.1 \mu \mathrm{m}$. Note that the color scales in each panel differ. 
(a) SEVIRI Land

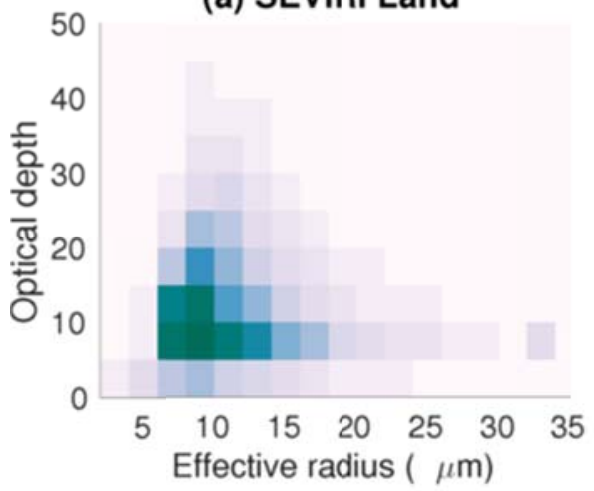

(c) MODIS Land

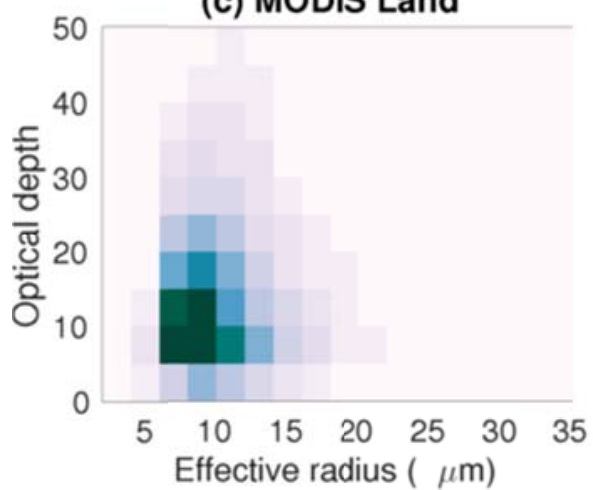

(b) SEVIRI Ocean

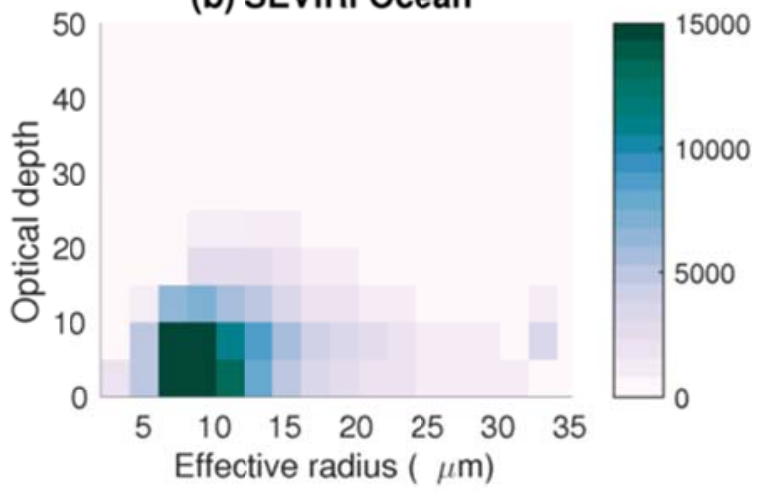

(d) MODIS Ocean
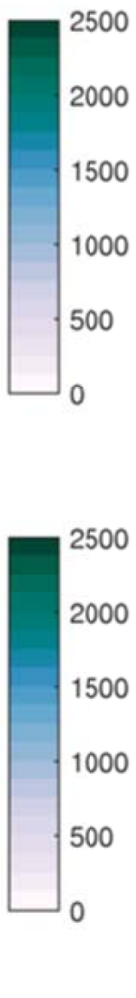

2000

1500

1000

500

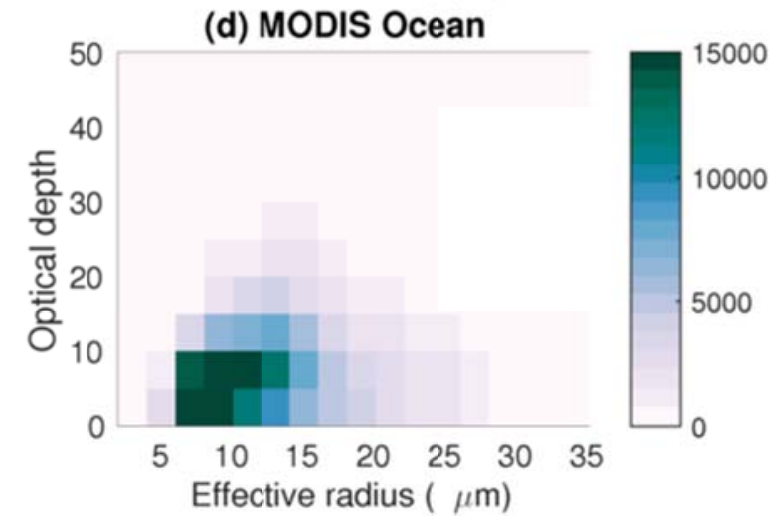

Figure 2. Joint histograms (in counts) of cloud effective radius $(\mu \mathrm{m})$ and optical depth from collocated warm cloud retrievals from (a, b) SEVIRI and (c, d) MODIS over land and ocean. The wavelength of the MODIS effective radius retrieval is $2.1 \mu \mathrm{m}$. Note that the scales for cloud properties over land (a,c) and ocean $(b, d)$ differ due to the different sample sizes. 
(a)

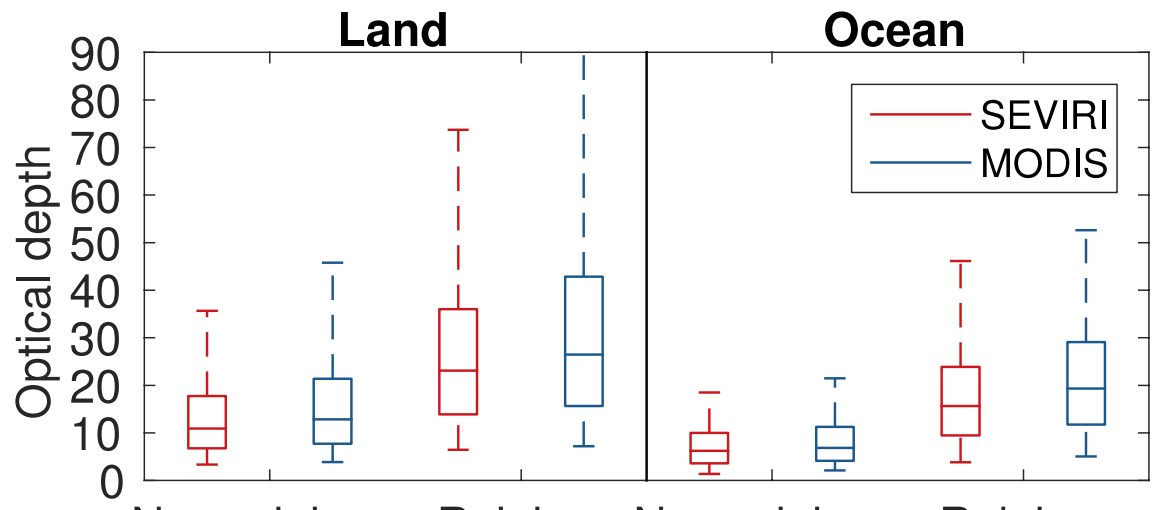

(b)

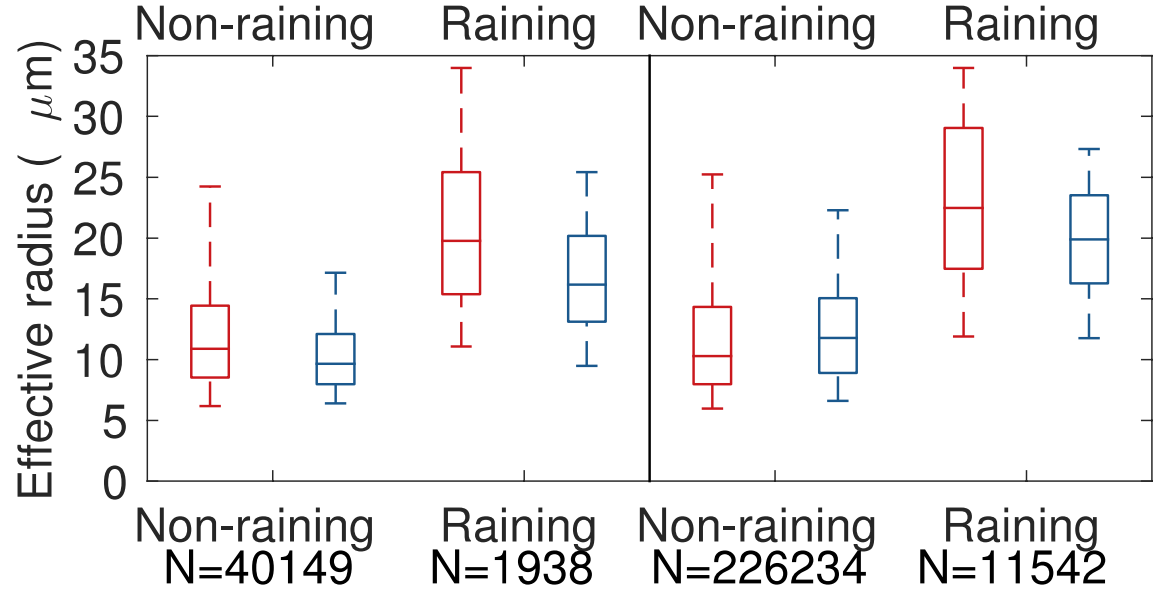

Figure 3. Boxplots of (a) optical depth and (b) cloud effective radius ( $\mu \mathrm{m})$ for collocated warm cloud retrievals from SEVIRI and MODIS over land and ocean during June-September 2007-2010. For each box, the line in the middle represents the median, the top and bottom edges represent the $25^{\text {th }}$ and $75^{\text {th }}$ percentiles, and the whiskers represent the $5^{\text {th }}$ and $95^{\text {th }}$ percentiles of the cloud property distributions. Non-raining and raining cloud retrievals are distinguished using the 'rain certain' flag provided by CloudSat 2C-PRECIP-COLUMN product. $N$ is the number of collocated non-raining and raining cloud retrievals. 


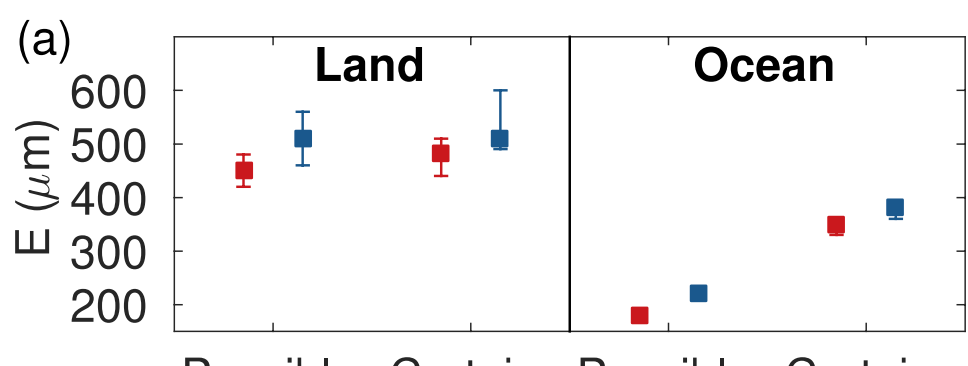

Possible Certain Possible Certain
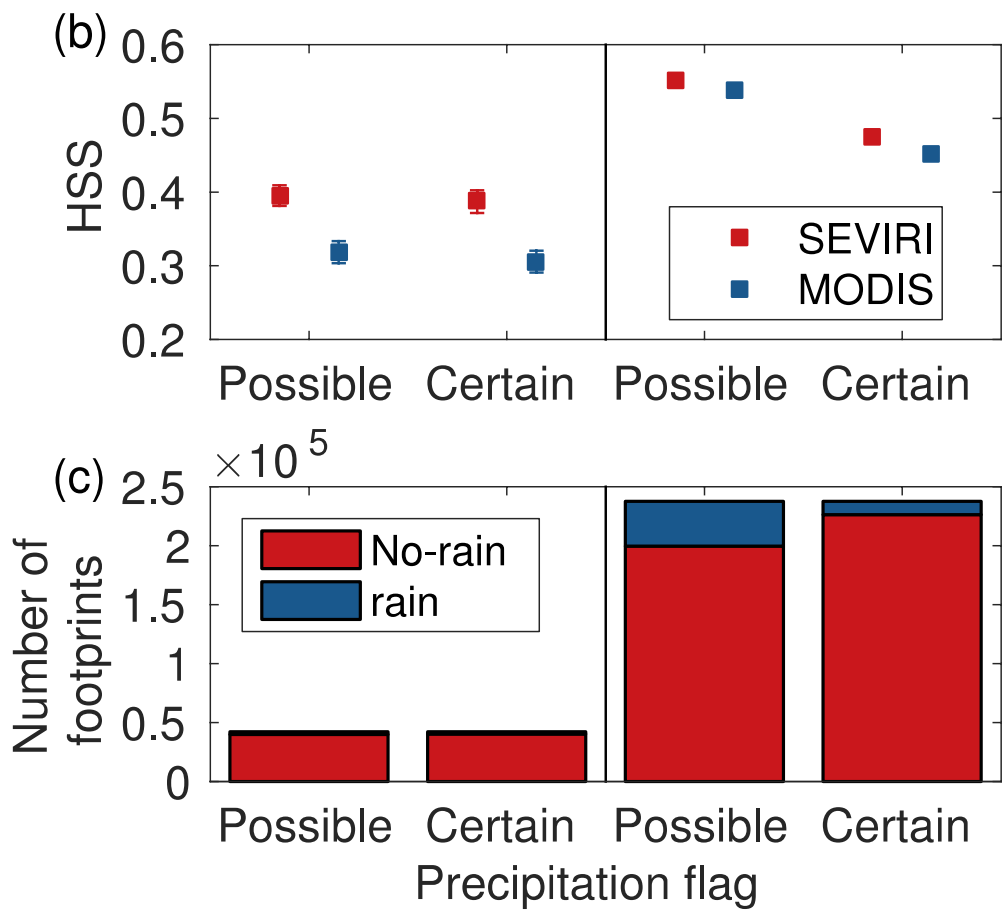

Figure 4. Plots of (a) optimal coefficient $E(\mu \mathrm{m})$, (b) Heidke Skill Score (HSS), (c) the total number of warm cloud and warm rain footprints, over land and ocean for collocated SEVIRI and MODIS cloud retrievals during JuneSeptember, 2007-2010. Warm rain delineation is tested using both the 'rain possible' and 'rain certain' precipitation flags from CloudSat 2C-PRECIPCOLUMN product. For optimal coefficient $E$ and HSS in (a) and (b), the squares represent the median value and the whiskers represent the $90 \%$ confidence interval calculated from bootstrap resampling the collocated dataset 1000 times. 


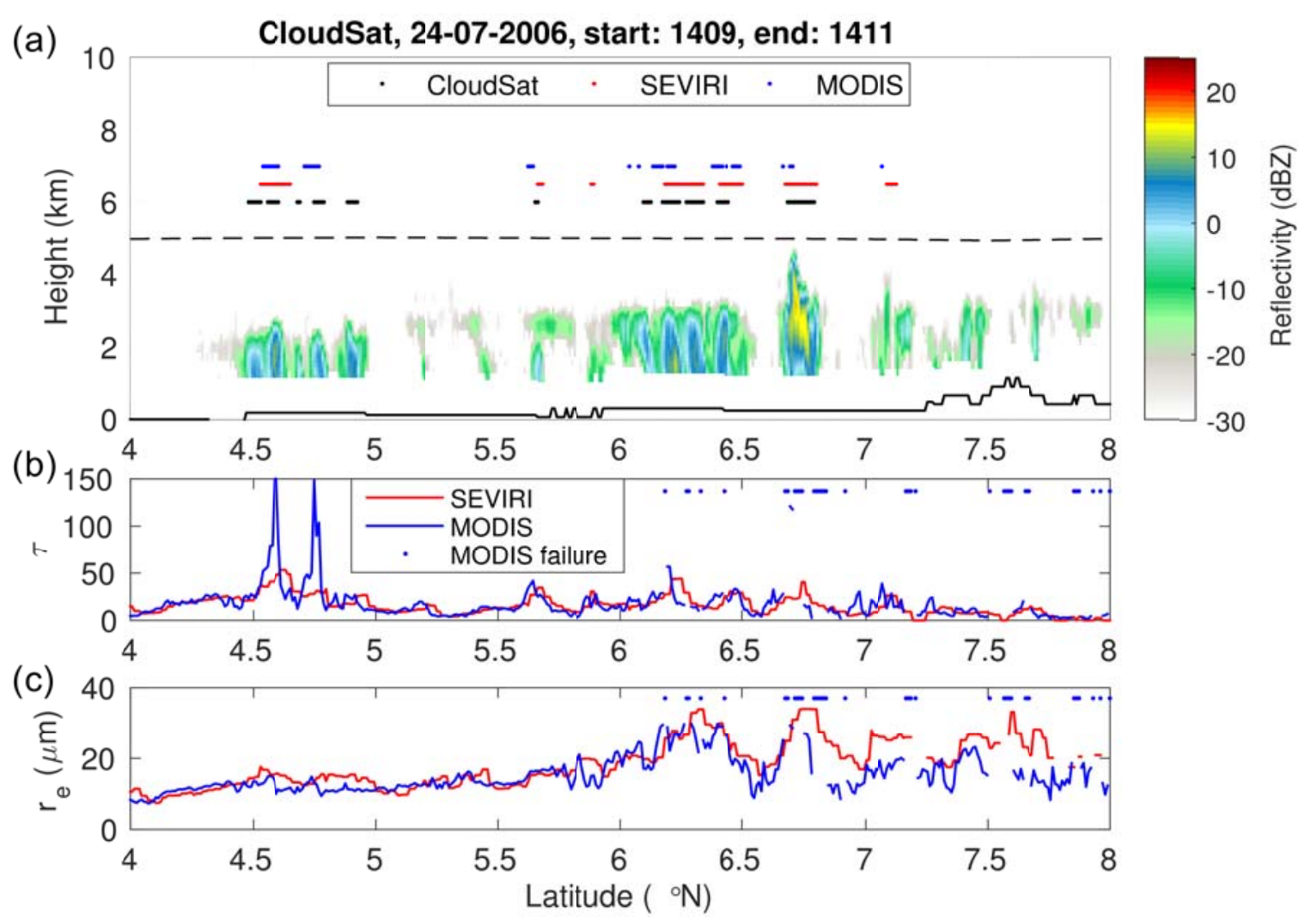

Figure 5. An example of warm rain events across southern West Africa between 1409-1411 UTC, 24 July 2006. (a) Height-time cross-section profiles of radar reflectivity (dBZ) from CloudSat, co-plotted with precipitation event indictors determined by the 'rain certain' flag in the CloudSat 2C-PRECIP-COLUMN product (block dots), CLASS-2 cloud retrievals with an optimal $E$ of $480 \mu \mathrm{m}$ (red dots), and MODIS cloud retrievals with an optimal $E$ of $580 \mu \mathrm{m}$ (blue dots). The dashed black line represents the freezing level height from ECMWF, while the solid black line in the bottom of the plot represents the topography. (b) and (c) represent the cloud optical depth and cloud effective radius, respectively, retrieved from CLASS-2 (red lines) and MODIS (blue lines), along with indicators showing where MODIS cloud property retrievals failed (blue dots). 


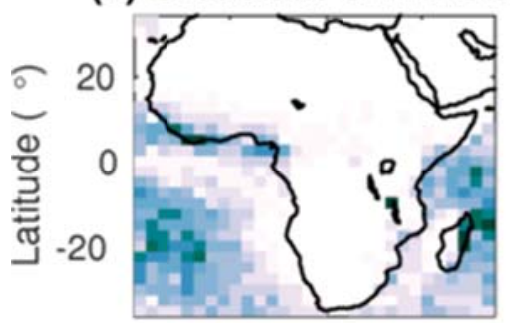

(d) CloudSat-CALIPSO

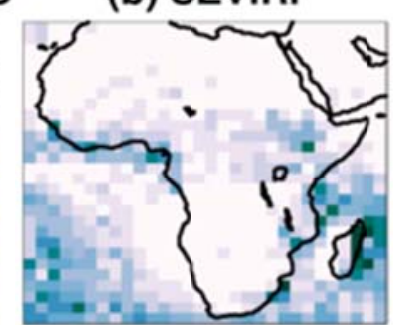

(e) SEVIRI

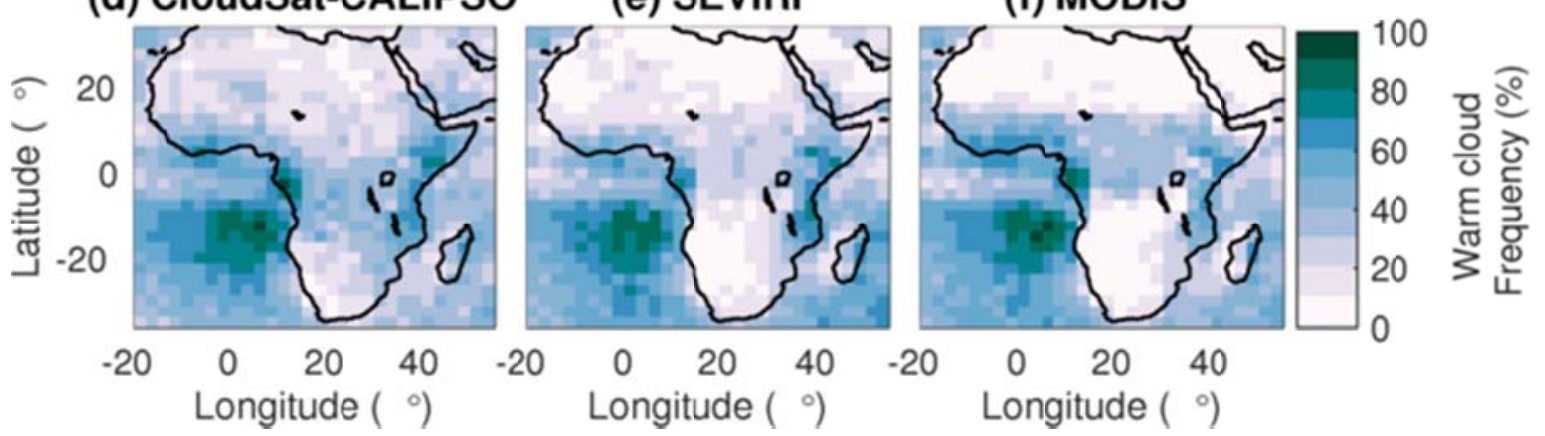

Figure 6. Geographic distributions of warm rain frequency (\%) from (a)

CloudSat, (b) SEVIRI, and (c) MODIS. (d)-(f) are the same as (a)-(c), but for warm cloud frequency (\%). All frequencies are computed with respect to the total number of collocated observations, at common grids of $2.5^{\circ} \times 2.5^{\circ}$. Median optimal $E$ values for the 'rain certain' criteria over land and ocean given in Table 2 are applied to SEVIRI and MODIS retrieval products. 
(a) SEVIRI

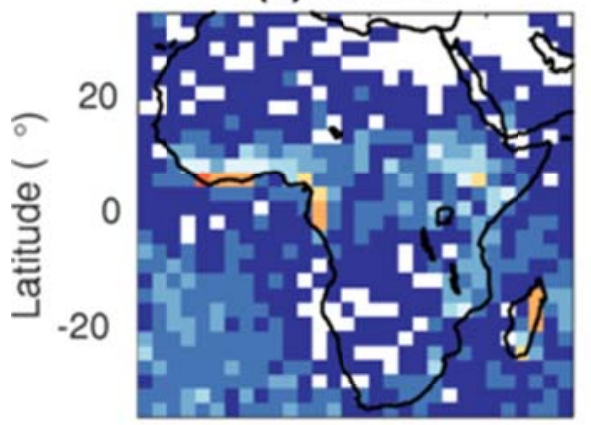

(c) SEVIRI

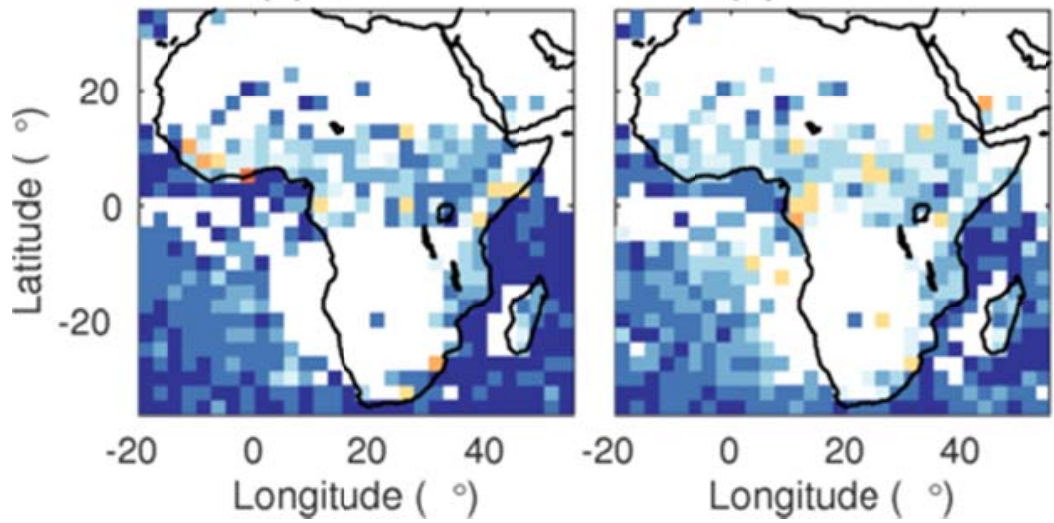

(b) MODIS

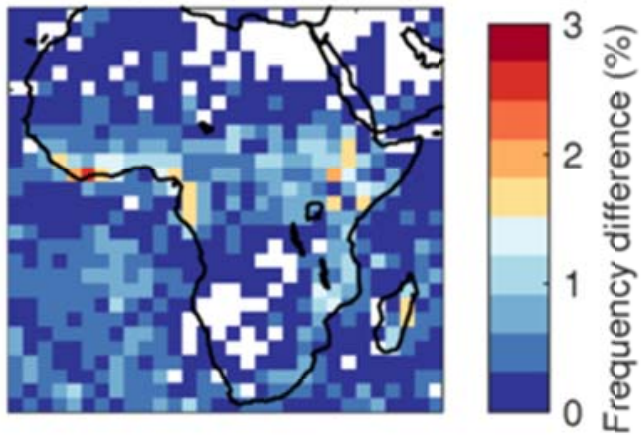

(d) MODIS

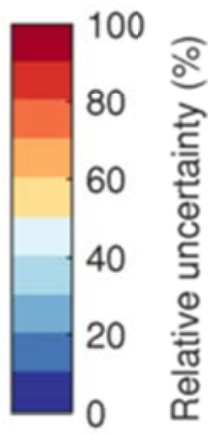

Figure 7. Warm rain frequency difference $(a, b)$ and relative uncertainty $(c, d)$ for SEVIRI (a, c) and MODIS (b, d). The frequency difference in (a) and (b) is the difference between warm rain frequencies derived from the $5^{\text {th }}$ and $95^{\text {th }}$ percentiles of optimal $E$ for the 'rain certain' criteria given in Table 2. The relative uncertainty (\%) in (c) and (d) is the frequency difference in (a) and (b), divided by the respective warm rain frequencies in Figures 6(b) and 6(c). 


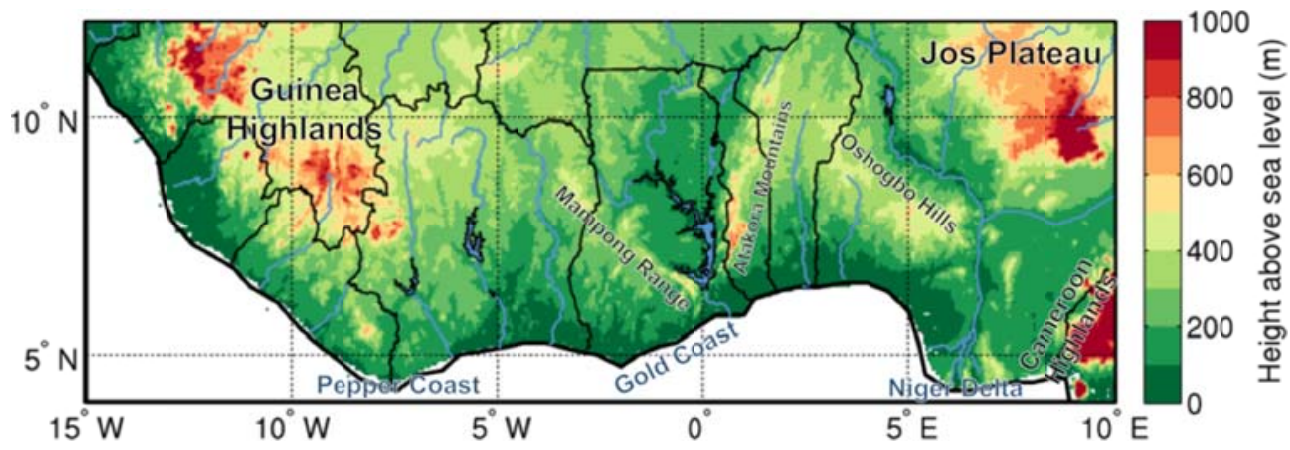

Figure 8. Regional topographic map of southern West Africa with colours representing the height above sea level $(\mathrm{m})$. 


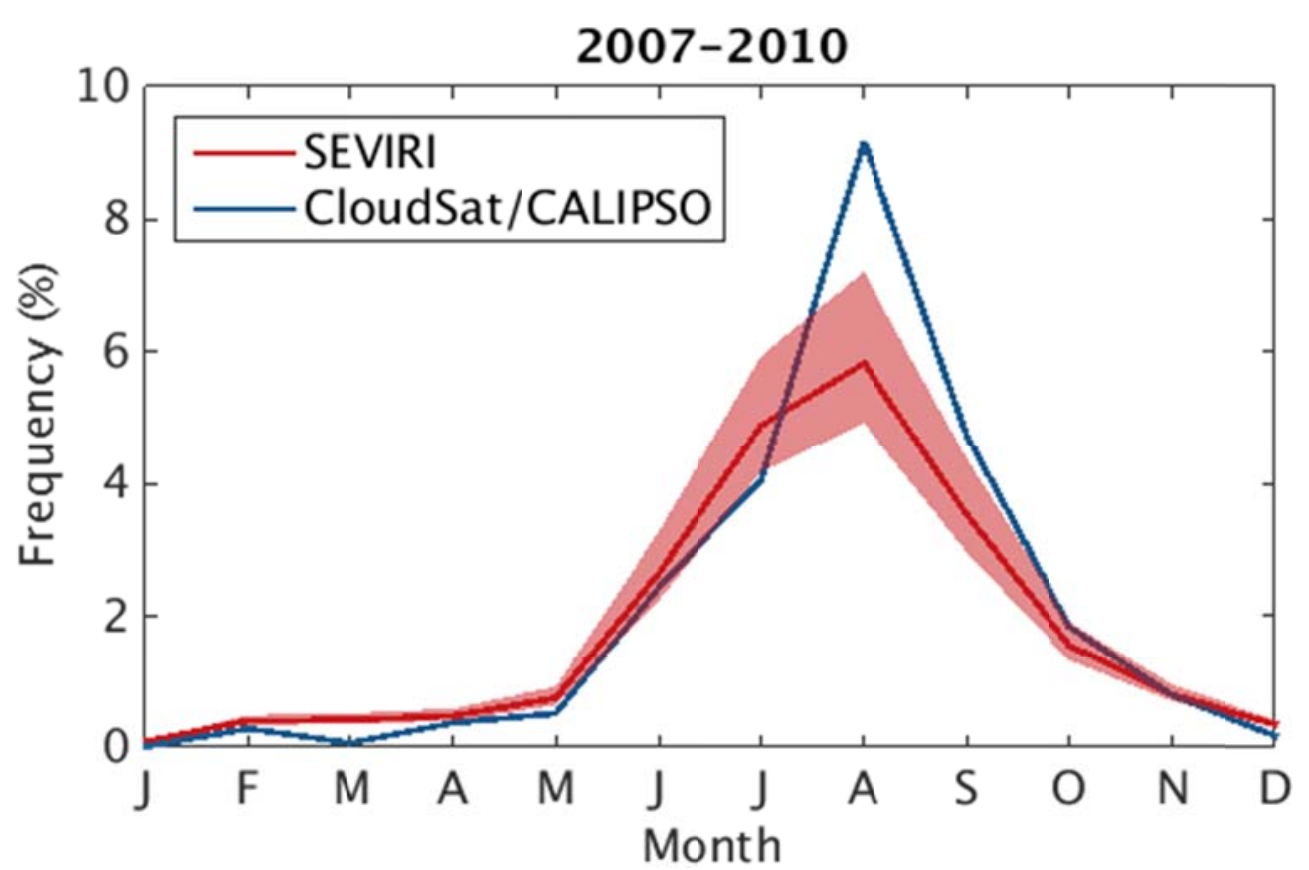

Figure 9. Seasonal cycles of SEVIRI warm rain frequency (1330-1430 UTC) and CloudSat/CALIPSO warm rain frequency over land in the region $10^{\circ} \mathrm{W}-0^{\circ} \mathrm{E}$, $4^{\circ} \mathrm{N}-8^{\circ} \mathrm{N}$ during $2007-2010$. The red line represents the optimal warm rain frequency from SEVIRI derived using the median optimal $E$, while the red shading represents the range of SEVIRI warm rain frequencies between the $90 \%$ confidence interval in optimal $E$ for the 'rain certain' criteria given in Table 2. CloudSat/CALIPSO statistics are derived using only daytime observations and 'rain certain' profiles. 


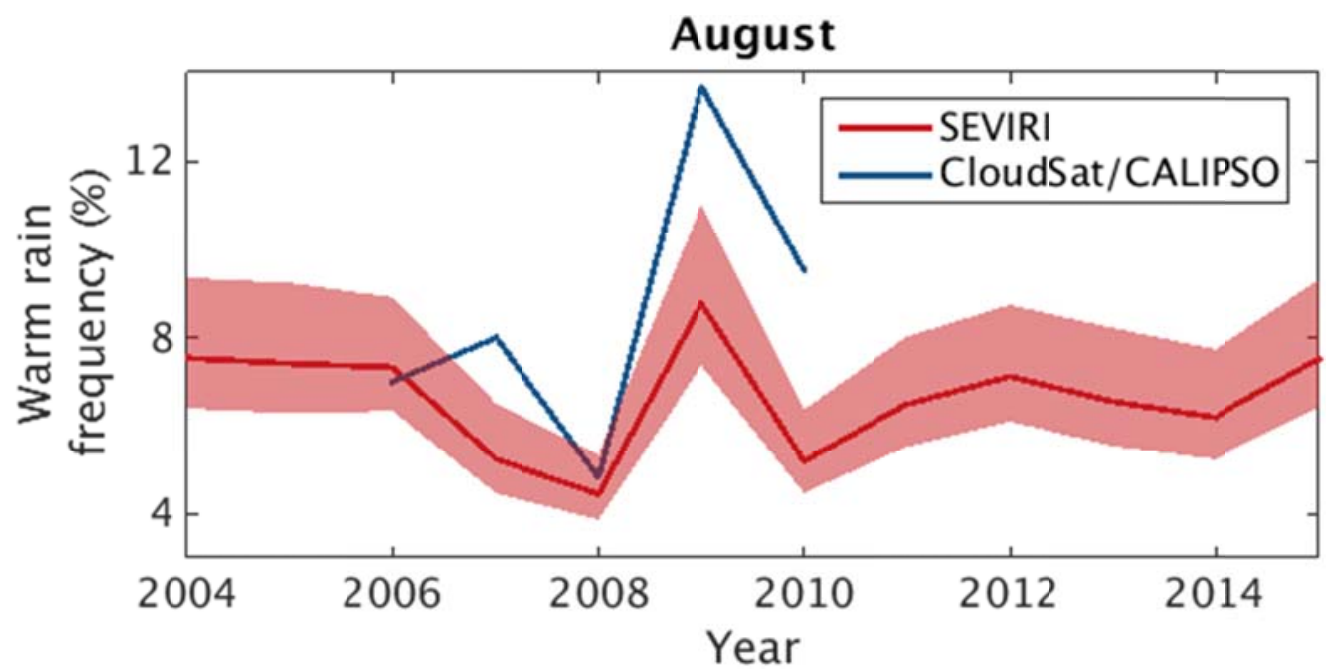

Figure 10. Interannual variability in warm rain frequency (\%) during August from SEVIRI (1330-1430 UTC) and CloudSat/CALIPSO over the region $10^{\circ} \mathrm{W}-$ $0^{\circ} \mathrm{E}, 4^{\circ} \mathrm{N}-8^{\circ} \mathrm{N}$. The SEVIRI warm rain frequency and range is presented as in Figure 9. 

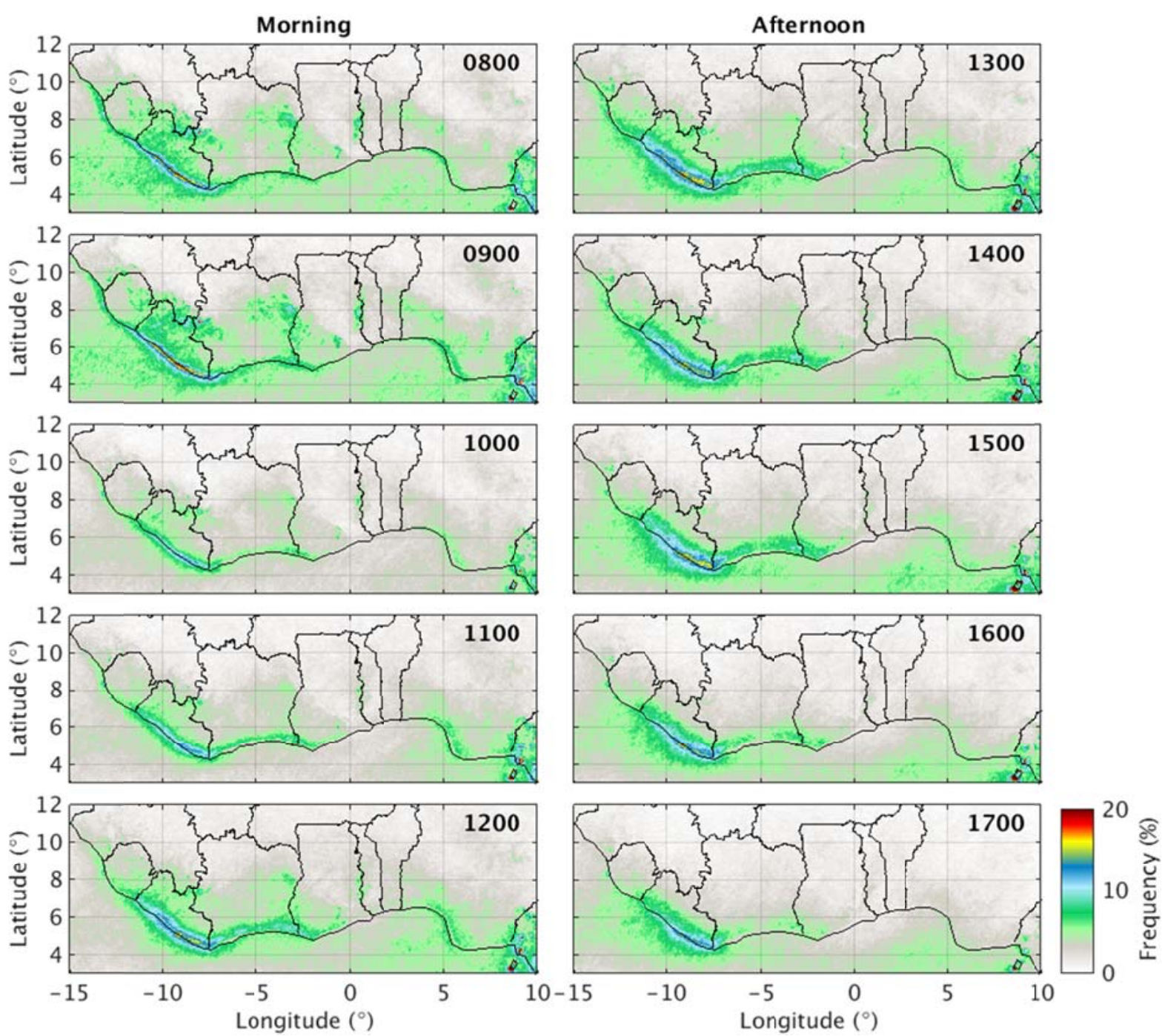

Figure 11. Daytime climatology of the frequency (\%) of warm rain over southern West Africa observed by SEVIRI during 0800-1700 UTC, June-

September 2004-2015. The climatology is derived by applying median optimal $E$ values for the 'rain certain' criteria over land and ocean given in Table 2 are applied to SEVIRI retrievals of cloud optical depth and effective radius. 


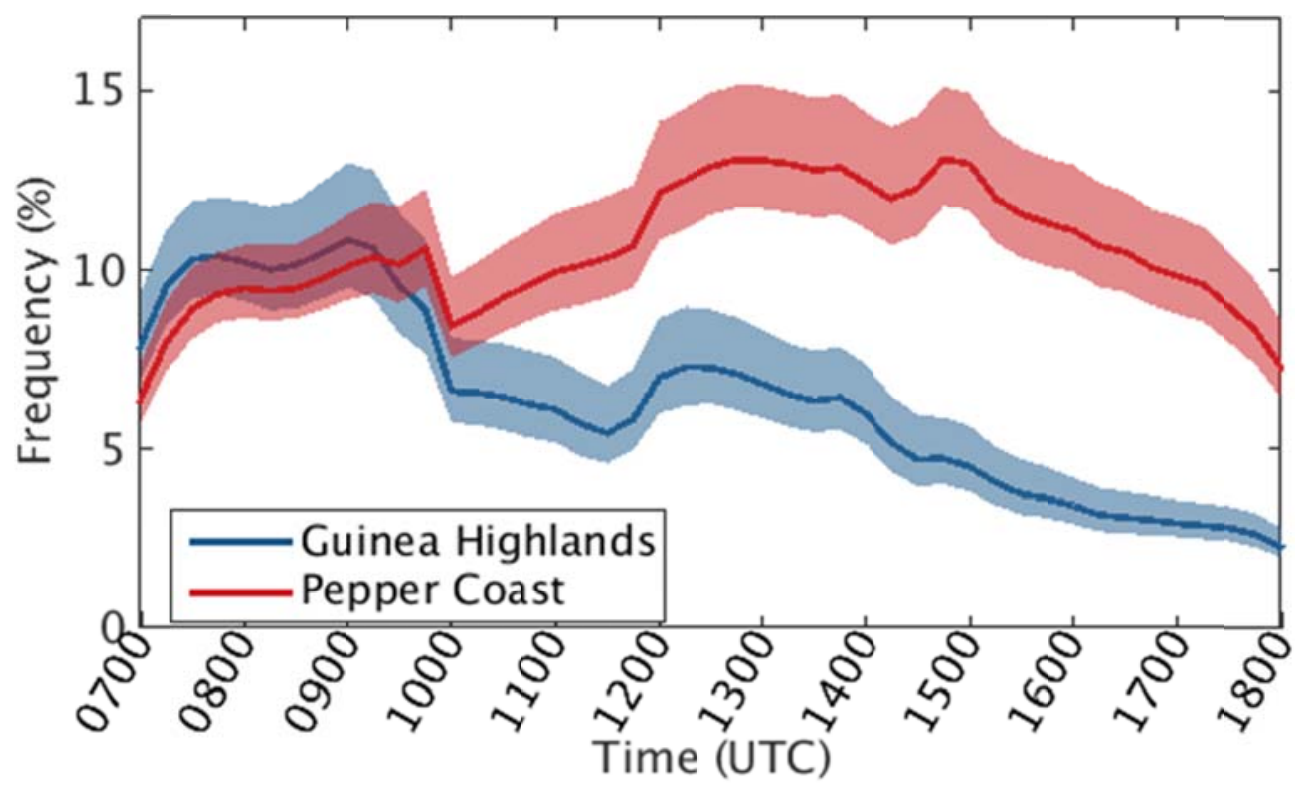

Figure 12. Warm rain frequency $(\%)$ over the Guinea Highlands $\left(7.9^{\circ} \mathrm{W}-8.3^{\circ} \mathrm{W}\right.$, $\left.7.1^{\circ} \mathrm{N}-7.5^{\circ} \mathrm{N}\right)$ and Pepper Coast $\left(8.6^{\circ} \mathrm{W}-9^{\circ} \mathrm{W}, 4.9^{\circ} \mathrm{N}-5.3^{\circ} \mathrm{N}\right)$ derived from $15-\mathrm{min}$ SEVIRI cloud properties during June-September 2004-2015. The line represents the optimal warm rain frequency derived using the median optimal $E$, while the shading represents the range of warm rain frequencies between the $90 \%$ confidence interval in optimal $E$ for the 'rain certain' criteria given in Table 2. 

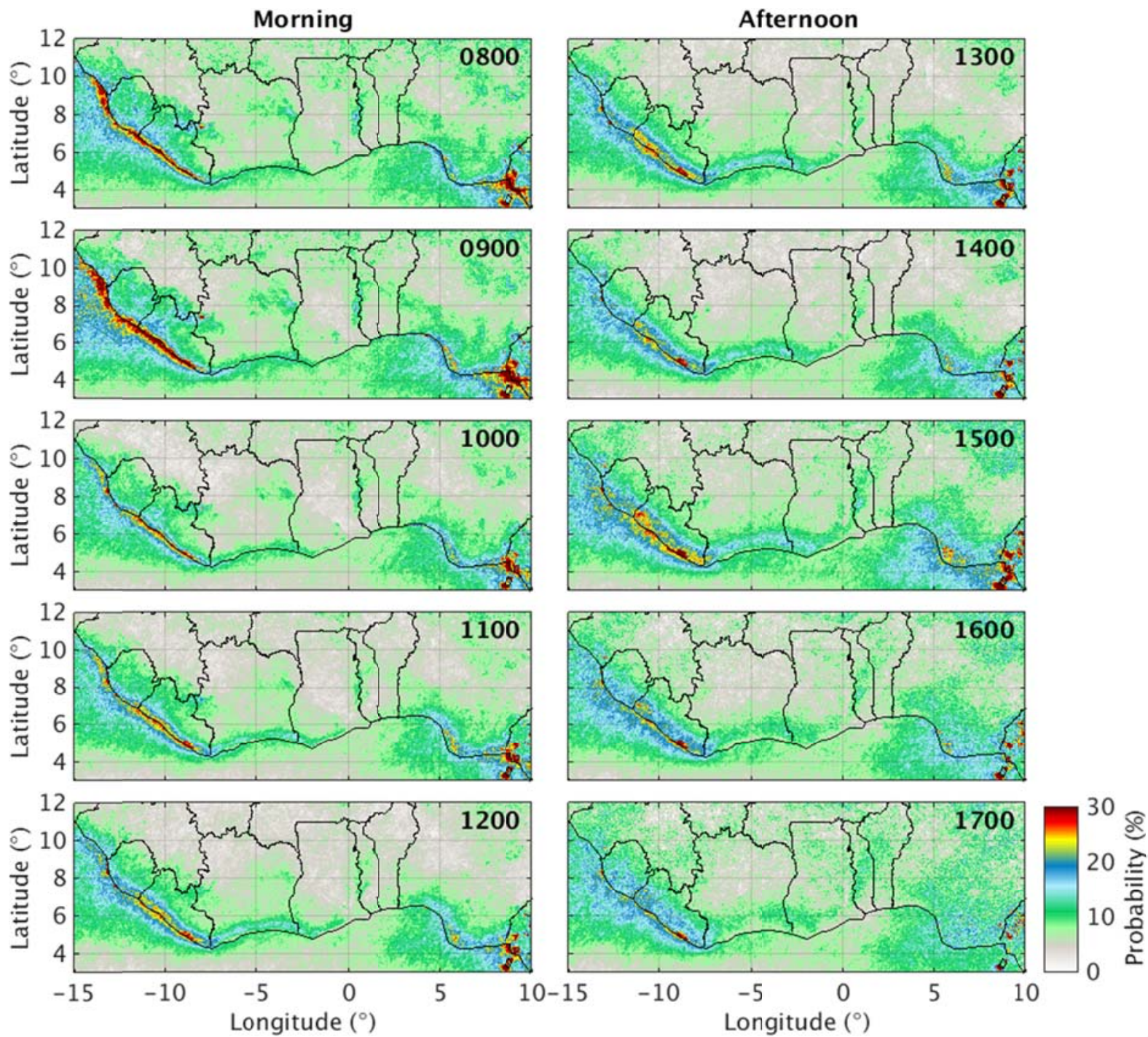

Figure 13. As Figure 11 but showing the probability of precipitation (POP, in \%) from warm clouds. 


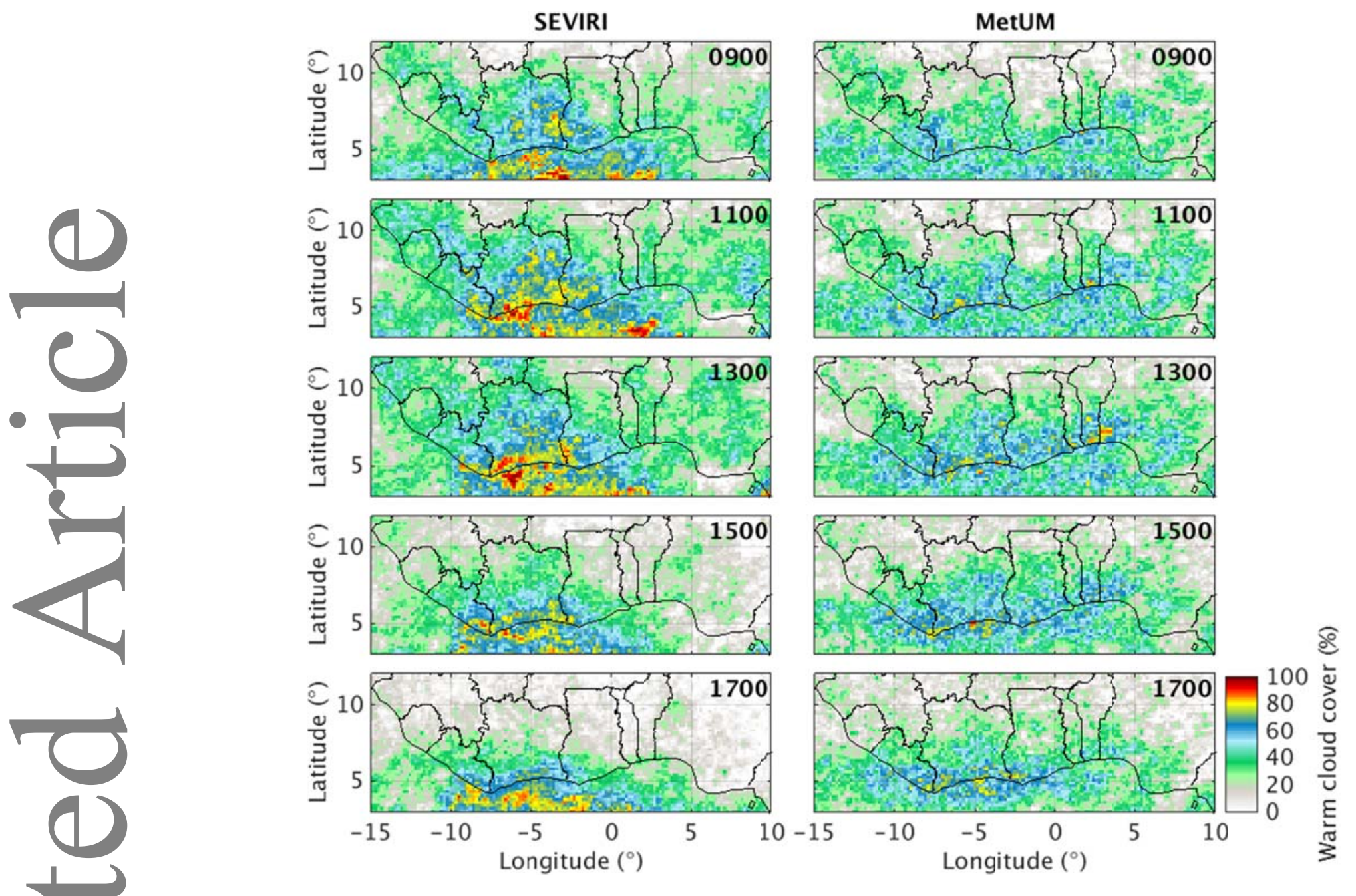

Figure 14. Warm cloud cover (\%) every 2 hours from 0900 to 1700 UTC between 27 July 2006 - 3 August 2006 from SEVIRI observations (left column) and MetUM simulations (right column). 


\section{SEVIRI}
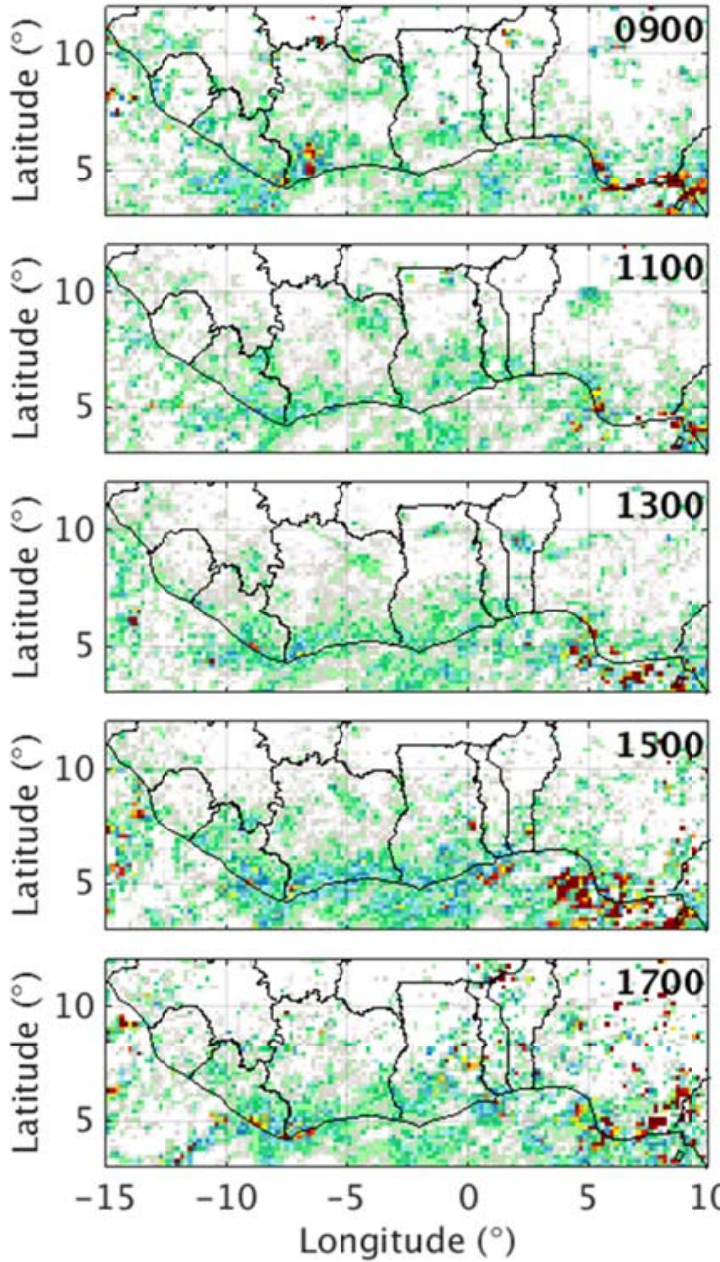

MetUM
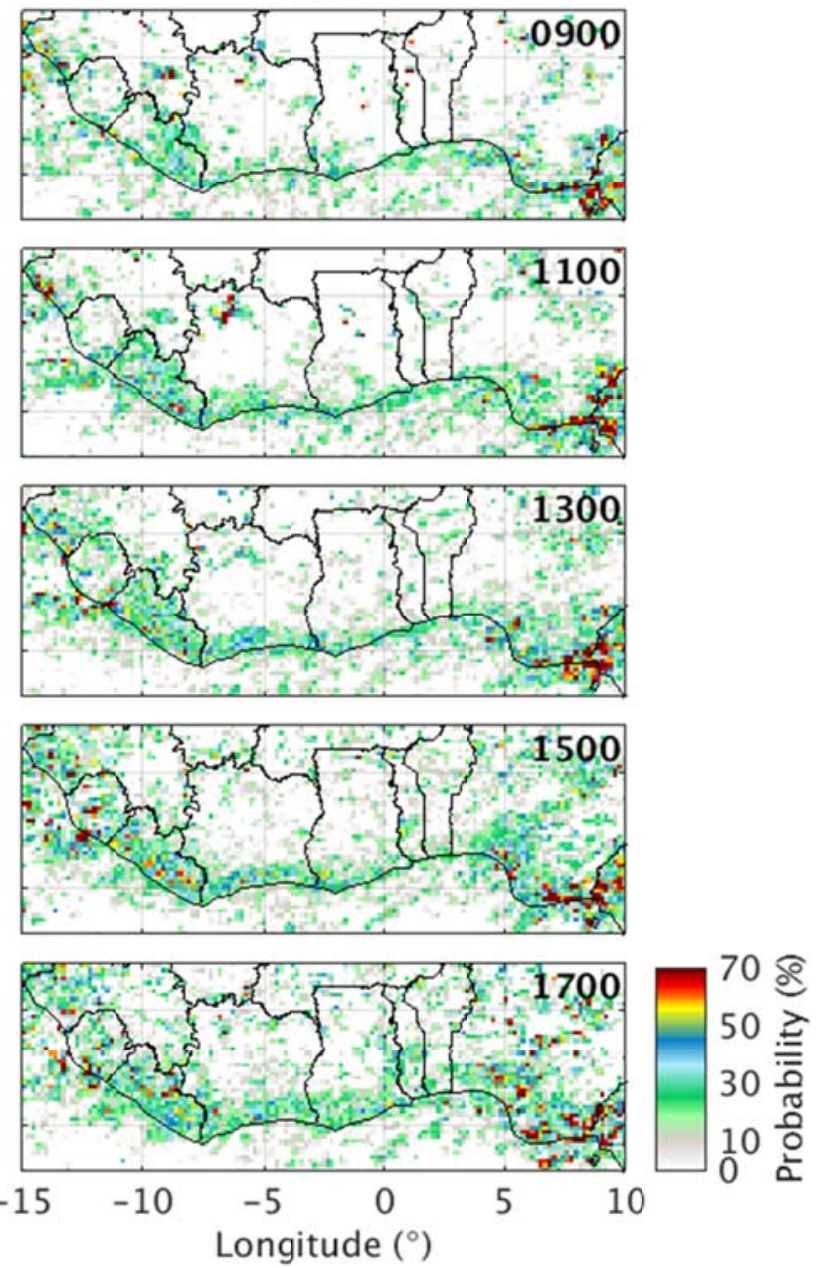

Figure 16. As in Figure 14 but for probability of precipitation (POP, in \%) from warm clouds. 